\title{
NON-LINEAR INCENTIVES, WORKER PRODUCTIVITY, AND FIRM PROFITS: EVIDENCE FROM A QUASI-EXPERIMENT
}

\author{
Richard B. Freeman \\ Wei Huang \\ Teng Li \\ Working Paper 25507 \\ http://www.nber.org/papers/w25507 \\ NATIONAL BUREAU OF ECONOMIC RESEARCH \\ 1050 Massachusetts Avenue \\ Cambridge, MA 02138 \\ January 2019, Revised February 2021
}

We are grateful to numerous seminar participants for their helpful comments. Errors are ours. The views expressed herein are those of the authors and do not necessarily reflect the views of the National Bureau of Economic Research.

NBER working papers are circulated for discussion and comment purposes. They have not been peer-reviewed or been subject to the review by the NBER Board of Directors that accompanies official NBER publications.

(C) 2019 by Richard B. Freeman, Wei Huang, and Teng Li. All rights reserved. Short sections of text, not to exceed two paragraphs, may be quoted without explicit permission provided that full credit, including $\odot$ notice, is given to the source. 
Non-linear Incentives, Worker Productivity, and Firm Profits: Evidence from a Quasi-experiment Richard B. Freeman, Wei Huang, and Teng Li

NBER Working Paper No. 25507

January 2019, Revised February 2021

JEL No. J00,J22,J3,M5,M52

\begin{abstract}
Using administrative data from a major Chinese insurance firm that raised its sales targets and rewards for insurance agents in a highly non-linear incentive system, we examine the effects of the changes on productivity, workers gaming the system, and the division of benefits from the new system between the firm and workers. We find that while the steeper incentive system creating the bunching distortions on which theories of non-linear incentives focus and other gaming behaviors by workers, the productivity increases dwarfed those costs. The magnitude and division of the productivity benefits improved the well-being of both the firm and workers. The firm gained about two-thirds of the higher net output, making the change profitable to it. Labor turnover fell, which suggests that the greater pay for workers from their one-third of the benefits exceeded the non-pecuniary cost of extra worker effort. The key to the success of non-linear incentives appears to rest more on its inducing workers to increase output than on its distortionary effects, suggesting that greater attention be given to the first order effects of motivating workers to produce more than to its incentivizing some distortionary behavior, which it does.
\end{abstract}

Richard B. Freeman

NBER

1050 Massachusetts Avenue

Cambridge, MA 02138

and NBER

freeman@nber.org

Wei Huang

NUS Business School

Mochtar Riady Building, \#7-76

15 Kent Ridge Driver, Singapore 119245

Singapore

huangw@nber.org
Teng Li

Xingang Xi Road 135, Guangzhou

China

ltsysu1990@gmail.com 


\section{INTRODUCTION}

Non-linear incentive systems are found widely in workplaces (Oyer, 2000). Economic studies show that workers respond to the non-linearity by taking distortionary actions that increase their income at the cost of efficiency --- for instance, bunching production at non-linear kink points or neglecting less incentivized activities. ${ }^{1}$ The benefits of such systems must exceed their costs for the firms that choose non-linear systems, but there is little compelling evidence on the benefits and costs of non-linear incentives, in part because firms that use such systems change them rarely (Larkin, 2014) and do not make their data available to researchers.

This paper analyzes a quasi-experimental reform in a non-linear compensation scheme for newly recruited sales agents by a leading insurance firm in China that provides new insight into what makes non-linear systems work despite the induced distortions. On January $1^{\text {st }}, 2015$ the Beijing headquarter of the firm made its compensation scheme more sharply non-linear with greater benefits for meeting thresholds in all its branches in China. Before the reform, the firm paid newly recruited sales agents in their $1^{\text {st }} 9^{\text {th }}$ tenure months a lump-sum bonus for meeting thresholds in life insurance commission. ${ }^{2}$ The reform raised the thresholds, increased the bonuses for meeting them, and extended the incentive system to agents for another three months, i.e., $10^{\text {th }}$ $12^{\text {th }}$ tenure months.

We obtained a proprietary dataset from the largest branch of the firm for our study. The dataset had detailed information on about 20,000 sales agents, including gender, education, urban status, age, job ladders, contract start/end date, and monthly insurance commission by insurance product,

\footnotetext{
${ }^{1}$ Oyer (1998) attributes manufacturing firms' sales increase over a fiscal year to non-linear incentives that lead agents to manipulate prices to influence the timing of customer purchases. Tzioumis and Gee (2013) show that mortgage officers increase output towards the end of a month to meet monthly quota so that mortgages on the last working day of a month have the highest likelihood of delinquency. Larkin (2014) shows that sales agents game the timing of deal closure to take advantage of a commission scheme. Benson (2015) shows that managers game the staffing and incentives of subordinates in response to quotas. Larkin and Leider (2012) suggest that nonlinear/convex piece rates attract and retain highly confident subjects, which may be beneficial in sales.

${ }^{2}$ Shaw, Gupta, and Delery (2000); Misra and Nair (2011); Chung et al. (2013) provide agency-based theoretic rationale for the use of commission and other output-based incentives.
} 
that allows us to study agent productivity, turnover rate, and branch profitability. Using an event study approach, we estimated the impacts of the reformed system in a narrow time window surrounding the reform --- from October 2014 to March 2015. The average life insurance commission increased hugely for agents with 12 or fewer months of tenure, by $38.5 \%$ for the newest hires to $53.7 \%$ for agents with $9^{\text {th }}-12^{\text {th }}$ tenure months. In contrast, life insurance commission of agents in their $13^{\text {th }}-18^{\text {th }}$ tenure months who were not covered by the non-linear incentive system showed little change.

We find that the reform had three adverse effects on agent productivity, as they sought to game the new incentive system. First, agents sold fewer insurance products not covered by the new system, per theories on multi-tasking (Holmstrom and Milgrom, 1991). Second, agents signed up more life insurance customers for whom the policies did not fit, leading the firm's screening department to reject them as unhealthy/unqualified customers, and increasing the number of consumers who themselves withdraw from a contract. ${ }^{3}$ Third, the non-linear incentive system produced a bunching of commissions just above threshold levels, consistent with the gaming literature (Oyer, 1998; Larkin, 2014). ${ }^{4}$ But agents gained so much through the sales increases in life insurance that their income increased substantially, despite the reduced sales of uncovered insurance products, increase in sales that were later withdrawn, and bunching distortion.

The finding that agents' income increased greatly under the new system does not invariably translate into comparable improvements in their net well-being. Much of the increase in income could have come at the expense of longer and more stressful work hours, offsetting in part the higher incomes (Bryson et al., 2012). We use the data on turnover to assess the magnitude of the net welfare benefit to agents from the new incentive system. We find that the turnover rate of the

\footnotetext{
${ }^{3}$ The insurance agent are not rigorously trained to detect unhealthy/unqualified customers. The screening department acts as the gate keeper to guarantee the quality of the customers.

${ }^{4}$ The bunching pattern has also been documented in analysis of responses to taxes and transfers, e.g., Saez (2010), Chetty (2012), and Kleven and Waseem (2013). See Kleven (2016) for a comprehensive review.
} 
agent covered by the new incentive system decreased by about 2.2 percentage points compared to the rate for those still paid by the old incentive system. ${ }^{5}$

Robustness tests show that the results hold up to different specifications. Analysis of selected groups shows a fairly even distribution of gains in productivity for gender, age, and urban status, with differences only among different education groups, where less educated agents increased productivity more under the new compensation scheme than more educated agents. Further, in terms of assessing causality, agent productivity showed no such changes in productivity in the same month of the past year when the reform did not happen.

The un-answered question of the gaming literature is whether firms gain from non-linear incentive systems given the distortions that any non-linear system is likely to induce (Lazear and Oyer, 2012). By the back-of-the-envelope calculations, we find that for the firm the improvement in the average life insurance premium under the new incentive system far outweighed the costs associated with the bunching distortions and other gaming behaviors. Specifically, about twothirds of the total return from the reformed incentive system went to the firm. Workers, as well as the firm benefited from the higher productivity. The key to the success of non-linear incentives appears to rest more on its inducing workers to increase output than on its distortionary effects, suggesting that greater attention be given to the first order effects of motivating workers to produce more than to its incentivizing some distortionary behaviors.

The rest of the paper proceeds as follows. Section 2 describes the organizational background and data. Section 3 presents the analytical framework and results for the impacts on agent productivity. Section 4 shows the empirical strategy and corresponding results for the effects on

\footnotetext{
${ }^{5}$ One related work is Lazear (2000). He finds that separation rates decrease after the compensation scheme switches from hourly wage to piecework.
} 
job ladder changes and agent turnover. Section 5 assesses the gains to workers and the firm and Section 6 concludes.

\section{ORGANIZATIONAL BACKGROUND AND DATA}

\subsection{Organizational Background and Compensation Scheme}

In 2012, the insurance industry in China had 3.3 million agents and made 1.5 trillion RMB insurance premium (roughly $3 \%$ of the nominal GDP). The insurance firm we studied hired 0.7 million agents across mainland China and made 322.1 billion RMB insurance premium (about 20\% of the total agents and premium in the industry) in 2012. Our worker performance data are from the firm's largest branch (hereafter, "the firm”), which is located in East China, where it employs around 20,000 agents and recruited about 3,200 new agents annually during our sample period. ${ }^{6}$

The firm pays newly recruited agents selling life insurance a predetermined commission percentage of each years' premium and bonuses for meeting threshold targets in the incentive plan. ${ }^{7}$ To limit the number of life insurance contracts sold to less healthy customers, the firm has a department that screens the qualification of new customers, with the power to require that customers take a physical examination before approving the contract and to cancel the sales if it judges the purchaser unqualified. Agents who sold short-run insurance not covered by the nonlinear plan received a lump sum commission when the customer signed the contract. ${ }^{8}$

The firm promotes or demotes agents quarterly based on an algorithm that assesses their sales of insurance and the number of new agents they refer to the firm (referrals) in the previous quarter.

\footnotetext{
${ }^{6}$ The city where the branch is located covers an area over $10,000 \mathrm{~km}^{2}$, had roughly 7 million residences, made 0.5 trillion RMB GDP (about 1\% of the nominal GDP) in 2012 .

${ }^{7}$ Insurance companies in China sign agency contracts with sales agents that are not covered by minimum wages.

${ }^{8}$ Life insurance covers the insured person for life and pays benefits to the beneficiary upon death of the insured. Short-run insurance covers a short period and pays out for prearranged conditions. The premium of contracts is standard so that agents cannot game the firm by lowering price when a few extra sales would reach a hurdle per Larkin's (2014) analysis.
} 
Agents are promoted on the firm job ladder for exceeding a rung-specific threshold, demoted for falling below a basic requirement, and left on the same rung otherwise. ${ }^{9}$

The firm's employee handbook "Regulations of Agents" (the regulations, hereafter) describes the compensation scheme, promotion algorithm, and other aspects of the agent job. The firm updates the regulations every two or three years based on feedback from its more than 250 branches across the country and developments in the insurance industry. ${ }^{10}$ Neither branch managers nor agents know the timing of an update nor the substance of the changes. ${ }^{11}$ As neither knew the firm would reform the incentive system in January 2015, we treat the reform as a quasi-experiment that identifies agent responsiveness to new incentives.

Insurance firms have high turnover. ${ }^{12}$ Prior to the reform, agents with tenure fewer than 12 months had a turnover of about $5.8 \%$ per month. Such a rate implies that over half of new recruits were gone within a year. Turnover then decreased to average monthly rates of $1.7 \%, 0.5 \%$, and $0.1 \%$, in the $13^{\text {th- }} 24^{\text {th }}, 25^{\text {th }}-36^{\text {th }}$, and $37^{\text {th }}-48^{\text {th }}$ tenure months. The non-linear incentive system is partially designed to reduce the turnover of new recruits.

The compensation scheme for new recruits. Prior to its 2015 reform, the firm had a non-linear compensation scheme for life insurance sales. Agents whose monthly life insurance commission satisfied a given threshold in their $1^{\text {st }}-9^{\text {th }}$ tenure months received a bonus. ${ }^{13}$ The dashed lines in

\footnotetext{
${ }^{9}$ Assessment months are January, April, July, and October. There are five rungs for sales agents, junior level I-III and senior level I-II; three rungs for managers, including team, department, and district managers where team is lowest rung and district is highest. Department and district managers manage other lower-level managers as well as their own teams. We assign 1-8 to rungs from sales agent junior I to district manager. The firm discourages outof-algorithm promotion. Only 37 out of 6,707 promotions in our data fell outside the algorithm.

${ }^{10}$ The firm's competitors also use high-powered incentive schemes to attract agents to work for them. Therefore, when the firm adjusts its compensation schemes, it considers its major competitors' strategies.

${ }^{11}$ Prior to the January $1^{\text {st }}, 2015$, the firm had reformed the regulations on March $1^{\text {st }}, 2006$, January $1^{\text {st }}, 2010$, and April $1^{\text {st }}, 2013$. The update time interval ranged from 2 to 3 years, and involved different changes in content. Neither branch management nor agents were likely to have predicted the reform date or changes.

${ }^{12}$ A 2016 PayScale comparison of turnover in Fortune 500 companies found high rates for insurance firms, with Massachusetts Mutual Life Insurance having the highest turnover and an average tenure of about 9 months.

${ }^{13}$ Agents who started before or on the $10^{\text {th }}$ of a month, were covered for the month. Agents who begin working after that are counted as starting from the next month. By plotting the distribution of contract start date of each month during our sample period, we do not find any evidence of the manipulation of contract start date.
} 
Figure 1 show the bonuses at different tenure months for the old system. Agents in the $1^{\text {st }}-3^{\text {rd }}$ tenure months received bonuses of 500, 800, 1,200, or 1,600 RMB for achieving 400, 800, 1,600, or 3,200 $\mathrm{RMB}$ in commission respectively, and thus earned a total income that ranged from below 400 RMB for those who failed to surpass the first hurdle to 900 RMB for reaching the first hurdle, 1,600 RMB for reaching the second, 2,800 RMB for the third, and 4,800 RMB for sales above the highest hurdle. A top seller thus earned more than ten times as much as an agent who sold below the first hurdle and 5.3 times more than an agent who just reached the first hurdle.

The new regulations that we study raised commission thresholds and bonuses and extended the period covered from the $9^{\text {th }}$ tenure month to the $12^{\text {th }}$ tenure month for newly recruited agents. The solid lines in Figure 1 show the profiles of the new compensation scheme. When agents in their $1^{\text {st }} 3^{\text {rd }}$ tenure months earned life insurance commission of $500,1,000,2,000,4,000$, and 8,000 $\mathrm{RMB}$, they received bonuses of $600,1,100,1,500,2,200$, and 3,500 RMB, respectively, producing incomes of $1,100,2,100,3,500,6,200$, and $11,500 \mathrm{RMB}$. The new system greatly steepened the non-linear incentives so that a top seller now earned more than 20 times an agent unable to surpass the first hurdle and 10 times more than an agent who just reached the first hurdle.

Although the firm offered other short-run insurance products, the scheme gave incentives solely for life insurance sales, which were more profitable due to higher premium and premium being paid annually for three to twenty years.

\subsection{Data and Sample Construction}

The firm provided us with data for job performance, personal attributes, and insurance claims for agents employed between January 2013 and December 2016. The job performance data consists of monthly commission from life insurance and other insurances sold, bonuses, insurance commission lost when customers or the firm's screening department canceled a contract (which 
we call "withdrawn commission", hereafter), and job ladders. ${ }^{14}$ To study the response of agents to the steepening of incentives, we focus on agents with tenure ranging from $1^{\text {st }}$ to $18^{\text {th }}$ month from October 2014 to March 2015 divided into five tenure-month groups, the $1^{\text {st }}-3^{\text {rd }}, 4^{\text {th }}-6^{\text {th }}, 7^{\text {th }}-9^{\text {th }}, 10^{\text {th }}-$ $12^{\text {th }}$, and $13^{\text {th }}-18^{\text {th }}$ tenure months that match the variation in the compensation scheme by tenure. This gave us data on 1,710,1,564, 953, 597, and 693 agents, respectively, during the sample period. Agents with $13^{\text {th }}-18^{\text {th }}$ tenure months who are ineligible for either the new or old compensation scheme are the comparison "untreated" group.

The personal information records agents' gender, age, highest education differentiated between polytechnic-school, high-school, 2-3 year college graduates, and bachelors and above; an indicator for whether the agent is from the urban area; and the start and end dates of their contract. ${ }^{15}$ Table 1 reports the summary statistics for our analysis sample: $66 \%$ of newly recruited agents are female; and the average education level is high-school graduation. Most of a newly recruited agent earnings come through selling life insurance: $75 \%$ of the monthly salary is from the insurance commission, of which life insurance commission accounts for around $85 \%$; with the remaining $25 \%$ is largely from bonuses.

We use the contract start and end dates to measure agent turnover. We compare the probability of leaving the firm for agents who joined between January and June 2015 and thus were "treated" by the new incentive system to agents who joined the firm between January and June 2013 and thus were not covered by the new incentive system. We track each agent for 18 months, with our sample period ending in December 2016.

\footnotetext{
${ }^{14}$ Figure A1 presents the fluctuations of life insurance, other insurance, and withdrawn commission by tenure month, respectively. One interesting pattern is that insurance commission significantly decreases after the $1^{\text {st }}$ tenure month and remains stable after the $7^{\text {th }}$ tenure month. It is a common phenomenon in the insurance industry as new recruits can sell insurance to their family members, relatives, and friends in the first few months in the firms. But after a few months, they may exhaust their networks. Consequently, their productivity may return to the average.

${ }^{15}$ The contract end date for an agent cannot be identified if she left the firm after the end of our sample period.
} 


\section{IMPACTS ON AGENT PRODUCTIVITY}

We examine first how the agents responded to the non-linear incentive system via sales of life insurance, other insurance, withdrawn commission, and bunching.

\subsection{The Response to the Incentive System via Increased Sales of Incentivized Insurance}

Event study. Following Dobkin et al. (2018) we use an event-study framework to show the monthly dynamics of adjustment reflected in life insurance commission.

$$
C_{i y m}=\sum_{r=-3}^{-2} u_{r}+\sum_{r=0}^{5} u_{r}+X_{i y m}^{\prime}+\varepsilon_{i y m},
$$

where $C_{i y m}$ is the outcome of interest for agent $i$ in year $y$ and month $m$, such as life insurance commission. $u_{r}$ are coefficients on the set of dummies of relative month $\mathrm{r}$ to the reform month. We treat December 2014 as the reference group with coefficients $\left(u_{-1}\right)$ normalized to zero. $X_{\text {iym }}^{\prime}$ is a vector of covariates, including gender, urban status, education level indicators, and age.

Figure 2 gives the coefficients on for the treatment and control group, respectively, in a regression that covers one season before and two seasons after the reform. The treatment group includes agents whose firm tenure is fewer than or equal to 12 months. Agents in their $13^{\text {th }}-18^{\text {th }}$ tenure months in the period are our control group. Before January 2015, the coefficients for both treatment and control groups are around zero. Just after the reform, the agents' commission in the treatment group increases sharply and remains at a higher level persistently over time, while in contrast, the agents' commission in the control group does not change significantly. The sharp change in the first month suggests that agents quickly figured out how to raise sales to meet the new targets and then kept doing what worked thereafter.

In Figure A2, we divide the treatment group into four categories (i.e., $1^{\text {st }}-3^{\text {rd }}, 4^{\text {th }}-6^{\text {th }}, 7^{\text {th }}-9^{\text {th }}$, and $10^{\text {th }}-12^{\text {th }}$ tenure months) and conduct the same analysis. Because of smaller samples, we have 
larger standard errors and a couple of point estimates which are out of order. But we find a fairly consistent pattern that life insurance commission in all the four groups increases sharply at the reform month and remains persistently higher than that in the control group after the reform.

In Figure A3, we provide a placebo test for whether our estimated productivity effects are contaminated by the start of a calendar year (i.e., "January effect"). Assuming that the compensation scheme changed in January 2014, we repeat our main analysis by using the sample period from October 2013 to June 2014 . The estimated coefficients of the $1^{\text {st }}-12^{\text {th }}$ and $13^{\text {th }}-18^{\text {th }}$ tenure-month groups are close to zero for before and after the pseudo-event month (January 2014), ruling out the possibility that the Figure 2 results reflect a "January effect".

Empirical specification. We use a simple econometric framework to estimate the overall effect of the new incentive system on life insurance commission. We compare the productivity of agents in three-month before and after the reform of the compensation scheme. The pre-treatment period is from October to December 2014, and the post-treatment period is from January to March 2015. The treatment group in the regression are agents whose firm tenure is fewer than or equal to 12 months divided according to tenure: the $1^{\text {st }}-3^{\text {rd }}, 4^{\text {th }}-6^{\text {th }}, 7^{\text {th }}-9^{\text {th }}$, and $10^{\text {th }}-12^{\text {th }}$ tenure months. Agents in their $13^{\text {th }}-18^{\text {th }}$ tenure months are our control group. For each category of the agents, we employ the following specification:

$$
C_{i y m}=\alpha_{0}+\alpha_{1} \text { Post reform } \text { for }_{\text {iym }} \alpha_{2}+\text { Tenure }_{\text {iym }}+\delta_{y m}+\varepsilon_{\text {iym }}
$$

where $C_{i y m}$ is the outcome of interest for agent $i$ in year $y$ and month $m$, such as life insurance,

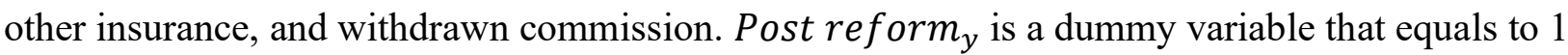
after the new incentive system's initiation. $X_{\text {iym }}^{\prime}$ has the same definition as that in equation (1). As a parallel analysis, we also replace $X_{i y m}^{\prime}$ with $\mu_{i}$ which represents the agent fixed effects that absorb differences in individual invariant unobserved characteristics (e.g., ability) and capture the 
individual selection effect. Tenur $e_{i y m}$ refers to the tenure month fixed effects. $\delta_{y m}$ is the calendar month linear trend, which captures any time trend in market demand for insurance products. $\varepsilon_{\text {iym }}$ is an idiosyncratic random error term. Standard errors in all regression analyses are clustered at the agent level.

The coefficient $\alpha_{1}$ in Equation(1) captures the average monthly post-reform productivity response for each agent category compared to the October to December 2014 benchmark. Since agents in their $13^{\text {th }}-18^{\text {th }}$ tenure months are not eligible for the old or new compensation scheme, we expect their estimated coefficient should be close to zero.

Regression results. Panel (A) of Table 2 records estimates of the average effects of the new compensation scheme on performance per Equation (2), where the outcome measure is life insurance commission net of withdrawn commission due to canceled contracts. In baseline estimates, columns (1)-(4) show that the new compensation scheme significantly raised the average life insurance commission for agents in different tenure month groups by $236.7\left(1^{\text {st }}-3^{\text {rd }}\right)$, 169.2 $\left(4^{\text {th }}-6^{\text {th }}\right), 102.1\left(7^{\text {th }}-9^{\text {th }}\right)$, and $128.2\left(10^{\text {th }}-12^{\text {th }}\right)$ RMB. By contrast, column $(5)$ shows no change in the commission for $13^{\text {th }}-18^{\text {th }}$ tenure month agents not covered by the new compensation scheme.

Although the regression sample is restricted to the narrow event-window --- from October 2014 to March 2015, the effects in baseline estimates could be driven by changes in agent unobservable characteristics before and after the reform of compensation schemes. To rule out this possibility, we add agent fixed effects and get coefficients comparable to those in baseline estimates. As the fixed effects analysis derives its estimation from the sales of the same agent over time, it is our strongest test of how non-linear incentives affect the productivity of individual agents. If the new system operated largely as a screening device, i.e., keeping and attracting more productive agents and weeding out less productive agents, the coefficients on the incentive system variable would shrink with inclusion of agent fixed effects. But Hausman tests indicate that the 
coefficients in the two specifications are not statistically significantly different from each other, suggesting that the effect of the new compensation scheme on productivity occurred mainly by changing efforts of the same agent.

Additionally, we note the large increase in life insurance commission for agents in the $10^{\text {th }}$ $12^{\text {th }}$ tenure months in all panel (A)'s specifications. As these agents were not included in the old incentive system, the estimated coefficient for them reflects the change in agent productivity changing from no incentive system to a non-linear incentive. The increase in this group is the second-highest among the four groups covered by the new system. Appendix Table A1 shows that the key factor in raising performances for the affected agents is through the increased probability that the agents attained the higher thresholds. ${ }^{16}$ Appendix Table A2 shows that the new compensation scheme raised the amount of bonuses going to agents.

All told, the new compensation scheme substantially raised agent performance. It increased life insurance sales for the four tenure groups by $38.5 \%$ ( $\left(1^{\text {st }}-3^{\text {rd }}\right.$ months $), 40.6 \%$, $\left(4^{\text {th }}-6^{\text {th }}\right.$ months $)$ $42.2 \%,\left(7^{\text {th }}-9^{\text {th }}\right.$ months $)$, and $53.7 \%\left(10^{\text {th }}-12^{\text {th }}\right.$ months $)$, respectively. Given that the increase in the threshold was smallest for the $1^{\text {st }}-3$ th month tenure group and largest for the $10^{\text {th }}-12^{\text {th }}$ month group, the percentage increase in sales divided by the percentage increase in income --- the elasticity of sales with respect to agent income --- falls with tenure, indicating that more tenured employees had greater difficulty in reaching the higher thresholds at the higher tenure. ${ }^{17}$

Finally, in panel (A) in Table A3 we employ a difference-in-differences specification that tests the robustness of our main results. In columns (1)-(4), the treatment groups are the agents in their

\footnotetext{
${ }^{16}$ Panel (A) shows that the probability of reaching the thresholds increased for each of the $1^{\text {st }}-12^{\text {th }}$ tenure months groups. The one exception is the bottom commission threshold for $4^{\text {th }}-6^{\text {th }}$ tenure-month group. This is because that commission threshold did not change in the new compensation scheme. Panel (B) shows no change in meeting thresholds for the $13^{\text {th }}-18^{\text {th }}$ tenure-month group uncovered by the incentives.

${ }^{17}$ The elasticity for the four tenure groups is $1.5,1.2,1.2$, and 0.8 . Taking the first group as an example, the elasticity is computed as $38.5 \% / 26 \%=1.5$. The percentage increase in income $(26 \%)$ is a combination of the estimates on life and other insurance commission and bonuses in panels (A) and (B) of Table 2 and Table A2. For the other three tenure groups, the income increased by $32.8 \%, 35.0 \%$, and $60.7 \%$, respectively.
} 
$1^{\text {st }}-3^{\text {rd }}, 4^{\text {th }}-6^{\text {th }}, 7^{\text {th }}-9^{\text {th }}$, and $10^{\text {th }}-12^{\text {th }}$ tenure months, respectively. The control group in all the four columns are the agents in their $13^{\text {th }}-18^{\text {th }}$ tenure months. Besides the agent and tenure month fixed effects, we control the year-by-month fixed effects. The coefficients are statistically significant, and the magnitudes of estimated effects are similar to those in panel (A) of Table 2.

\subsection{Gaming the Incentive System via Reduced Sales of Non-Incentivized Insurance and}

\section{Increased Withdrawn Contracts}

By increasing payments only for life insurance, the compensation scheme gave agents incentives to divert efforts from selling other products. ${ }^{18}$ Panel (B) of Table 2 presents estimates of the impact of the new compensation scheme on the commission of other insurance items for agents in the $1^{\text {st }}-3^{\text {rd }}, 4^{\text {th }}-6^{\text {th }}, 7^{\text {th }}-9^{\text {th }}$, and $10^{\text {th }}-12^{\text {th }}$ tenure months. The commission earned on these products decreased by 20 to $25 \mathrm{RMB}$ for the various groups --- statistically significantly greater than zero in most cases but costing only $15 \%$ of the estimated increase in life insurance commission induced by the new compensation scheme.

The high-powered compensation scheme also gives agents an incentive to trade-off the quality of a sale for numbers of sales. ${ }^{19}$ In their pitch to customers, agents may overstate the benefits of the life insurance to some at the risk that the customers will later decide that the contract does not fit their needs and withdraw from it. Similarly, agents had greater incentive to accept marginally less healthy (unqualified) consumers at the risk that the firm's screening department cancels the sale. These situations show up as "withdrawn commission" --- a negative line on the commission accounting. ${ }^{20}$ Panel (C) of Table 2 shows that the new compensation scheme increased the

\footnotetext{
${ }^{18}$ This is captured by theories on multi-tasking (Holmstrom and Milgrom, 1991)

${ }^{19}$ This fits with other studies of monetary and nonmonetary incentives affecting performance --- DellaVigna and Pope (2017)'s analysis of the effect of monetary and non-monetary incentives on effort. Ager et al. (2016)'s analysis of German pilots during World War II; and Li and Lu (2018)'s analysis of how performance of award winners responds to peer pressure.

${ }^{20}$ Agents normally receive their salary after the firm has dealt with all withdrawn cases and thus cannot make money selling insurance to "fake" customers who withdraw their contracts later on.
} 
withdrawn commission in all tenure month groups subject to the new system relative to the control group, which had no significant change. The increased withdrawn commission is about $27 \%$ of the increased life insurance commission inclusive of the withdrawn commission, implying that agents significantly reduced the quality of sales, presumably to reach threshold hurdles. ${ }^{21}$

\subsection{Bunching Distortions}

Figure 3 displays the distribution of monthly life insurance commission around the lowest commission threshold of the old and new compensation schemes. If workers are gaming the system, we would expect to find the life insurance commission bunched just above the threshold.

Panel (A) shows that in the $1^{\text {st }} 3^{\text {rd }}$ tenure months life insurance commission was bunched just above the new 500 RMB, up 100 RMB from the old system's lowest threshold of 400 RMB, which seem most readily explained by the non-linear incentives inducing agent gaming behavior. ${ }^{22}$

Panel (B) of Figure 3 displays the distribution of monthly life insurance commission around the 800 RMB bottom threshold for the $4^{\text {th }}-6^{\text {th }}$ months tenured workers. Since this threshold did not change with the new compensation scheme, the bunching should not change, and indeed that is what the data show. By contrast, the distributions around the top commission threshold for the $4^{\text {th }}$ $6^{\text {th }}$ tenure month group for whom incentives changed show a bunching around $2,000 \mathrm{RMB}$ under the new compensation scheme compared to a relatively uniform distribution of commissions under the old system (see Figure A5 panel (B)). Panels (C) and (D) show similar bunching in the

\footnotetext{
${ }^{21}$ Panels (B) and (C) in Table A3 show that the results on other insurance commission and withdrawn commission are qualitatively and quantitatively similar by using the difference-in-differences specification.

${ }^{22}$ There are two other possible explanations for the bunching. It might reflect a sorting mechanism where those who could not reach the threshold left the firm. However, this would likely produce an increase in turnover, contrary to the observed fall in turnover. Alternatively, the firm might have selected the threshold so most sales agents could pass it, which runs counter to the whole point of the steepening incentives change. Figure A4 gives the distribution of monthly life insurance commission around other commission thresholds of the old and new compensation schemes for the 1st-3rd tenure month group. Bunching distortions are more salient at the lower commission thresholds than at the higher ones, possibly because fewer agents have the ability to manipulate productivity at the higher thresholds.
} 
distribution of life insurance commission for agents in their $7^{\text {th }}-9^{\text {th }}$ and $10^{\text {th }}-12^{\text {th }}$ tenure months, respectively.

\section{IMPACTS ON JOB LADDERS AND TURNOVERS}

\subsection{The Promotions and Demotions}

As noted in Section 2, the firm assesses agents at the beginning of each quarter on their previous quarters' performance and moves them along the job ladder if performance was above or below the specified criterion. Since the commission earnings factor into promotion, the new compensation scheme may increase promotions and reduce demotions.

Panel (A) of Figure 4 shows that agents were promoted to significantly higher job ladders in their first 12 months in the firm for those fully covered by the new compensation scheme compared to those covered by the old scheme. Panel (B) presents job ladder changes for each tenure-month group. We calculate the numbers by taking the difference between job ladders at the start of next season and this season. For instance, for the $4^{\text {th }}-6^{\text {th }}$ tenure-month group, we take the difference between job ladders at the start of July and start of April. This figure shows that the new incentive system induced more promotions or fewer demotions, except for the $4^{\text {th }}-6^{\text {th }}$ tenure-month group.

Empirical specification. We track each agent's $1^{\text {st }}-18^{\text {th }}$ months in the firm. We compare job ladder changes between agents recruited between January and June 2015 , whose $1^{\text {st }}-18^{\text {th }}$ tenure months were under the new scheme to job ladder changes for agents recruited two years earlier between January and June 2013, whose $1^{\text {st }}-18^{\text {th }}$ tenure months were under the old scheme. Combining the two groups, we examine job ladder changes by estimating the following equation:

$$
\begin{aligned}
Y_{\text {iym }}= & \gamma_{0}+\gamma_{1} \text { Post reform } \\
& * \text { Tenure }_{i y m}^{1^{\text {st }}-12^{\text {th }}}+\gamma_{2} \text { Post reform } \\
& W_{i y m}^{\prime} \gamma_{4}+\gamma_{3} \text { Tenure }_{\text {iym }}^{1^{s t}-12^{\text {th }}}+\epsilon_{\text {iym }}
\end{aligned}
$$


where $Y_{\text {iym }}$ is the changes in the agent position on the firm's job ladder with the values of 1 for promotion, 0 for no change, and -1 for demotion in year $y$ and month $m$. Tenure $e_{i y m}^{1^{s t}-12^{\text {th }}}$ is a binary variable equal to1 if year $y$ month $m$ is in $i$ 's $1^{\text {st }}-12^{\text {th }}$ tenure months. $W_{i y m}^{\prime}$ is a vector of demographic variables, including gender, urban status, education level indicators, and age. $\pi_{m}$ refers to the calendar month fixed effects, capturing the seasonal variations of the insurance demand. $\epsilon_{i y m}$ denotes an idiosyncratic random error term. The other notations are as in Equation (2). The key coefficient is $\gamma_{1}$, which measures the average effect of the new compensation scheme on job ladder changes for agents in the $1^{\text {st }}-12^{\text {th }}$ tenure month group, relative to the $13^{\text {th }}-18^{\text {th }}$ tenure month group. The coefficient $\gamma_{2}$ captures the effect on agents' job ladder changes in the $13^{\text {th }}-18^{\text {th }}$ tenure month group who were not covered by the new nor old scheme and thus should be close to zero. Standard errors are clustered at the agent level.

Regression results. Given the nature of the dependent variable, we estimate an ordered logistic model of the effects of the new system on job ladder changes. Column (1) in Table 3 shows that the new compensation scheme was associated with a significant advance up the job ladder for agents in their $1^{\text {st }}-12^{\text {th }}$ tenure months compared to the $13^{\text {th }}-18^{\text {th }}$ tenure-month control group. By contrast, the job ladders of the control group of $13^{\text {th }}-18^{\text {th }}$ tenure month agents did not change significantly.

Converting the estimated coefficients in column (1) into probabilities, agents in their $1^{\text {st }}-12^{\text {th }}$ tenure months had a higher probability of being promoted under the new compensation scheme by $1.26 \%$ and a lower risk of being demoted by $1.44 \%$. Column (2) shows that the estimated coefficients of promotion and demotion of agents in their $4^{\text {th }}-6^{\text {th }}$ and $10^{\text {th }}-12^{\text {th }}$ tenure months are significantly higher while the coefficients for the $1^{\text {st }}-3^{\text {rd }}$ and $7^{\text {th }}-9^{\text {th }}$ tenure-month groups are positive but statistically insignificant under the new compensation scheme. 


\subsection{The Welfare of Agents --- Turnover Rate}

Meeting higher thresholds that pay greater bonuses can come at the expense of longer and more stressful work hours, offsetting in part the higher incomes per Bryson et al.'s (2012) finding that higher-paid British workers suffered from increased job anxiety. Absent reports on job satisfaction from agents, we use the data on turnover to assess the magnitude of the net welfare benefit to agents from the new system. If agents "paid" for the higher performance through more stressful work, some would likely have found the job no longer attractive and have left more quickly than under the previous incentive system, raising turnover. Those who stayed would also have paid a price for their higher income. If, on the other side, the income gain from the new system dominated the cost of greater time and effort to attain targets, the job would have gotten more attractive, reducing turnover.

Panel (A) of Figure 5 shows that agent turnover was markedly lower in their first 12 months in the firm for those fully covered by the new compensation scheme compared to those covered by the old scheme. Panel (B) presents the turnover rate for each tenure-month group. We take the difference between cumulative turnover rate at the end and start of each season to derive the numbers. For instance, we calculate the turnover rate for the $4^{\text {th }}-6^{\text {th }}$ tenure-month group as the difference between cumulative turnover rate at the end of June and start of April. This figure shows that under the new incentive system turnover rates decreased for agents in their $4^{\text {th }}-12^{\text {th }}$ tenure months. The implication is that the higher income under the new compensation scheme made working for the firm more attractive relative to any increase in agent stress.

Column (3) in Table 3 estimates the magnitude of the reform in compensation scheme on turnover using Equation (3) by comparing the turnover of agents recruited in 2015 and paid by the new incentive system to those recruited in 2013 and paid by the old scheme. The estimate shows a 2.2 percentage point lower turnover rate of agents in the $1^{\text {st }}-12^{\text {th }}$ tenure months in the new 
incentive system relative to those in the same tenure months in the old scheme. By contrast, the turnover rate of the agents in their $13^{\text {th }}-18^{\text {th }}$ tenure months, for whom the incentive system did not change, did not differ significantly. Column (4) gives estimates of the effect on the turnover rate for each tenure-month group separately. Compared to the $13^{\text {th }}-18^{\text {th }}$ tenure-month group, the turnover rate of agents in all other tenure month groups decreased significantly for all but the $1^{\text {st }}$ $3^{\text {rd }}$ tenure-month group.

In short, the reduction in turnover suggests that the new incentive system created a "welfare surplus" for agents rather than costing them so much effort and time to be just marginally beneficial. Perhaps the improvement in productivity came more from the workers thinking harder about how to do their job and identify good potential customers quickly or to improve their sales pitch to prospective customers than through more painful greater effort. ${ }^{23}$

\section{DISCUSSION: WELFARE OF THE FIRM}

What about benefits to the firm? The gains to the firm consist of the increased revenue associated with the new incentive system less the costs paid to labor less the administrative expense to the firm of developing and implementing the new system. Table 4 shows our estimates of these benefits and costs. The gains from increased sales of life insurance due to the commission mode of pay dominate the revenue lost from sales on non-incentivized products and cancellations of sales. Most of the gain in agents' income comes from the increased commission on sales. With a commission rate of $15 \%$ on sales, $85 \%$ of the additional revenues went to the firm, giving it the bulk of the increased net revenue stream. But the agents gained as well through the bonuses, which benefit them but are a cost to the firm. Taking account of bonuses reduces the firm share of the additional revenues by about $9.64 \%$.

\footnotetext{
${ }^{23}$ See Kahn et al. (2018) and Kaur, Kremer, and Mullainathan (2015).
} 
What is missing in this calculation is the time and money for the firm to develop and implement the new system, on which our data are silent. To get some notion of the magnitude of administrative costs of changing and operating the non-linear incentive system, we used the annual reports of the firm. The annual reports for 2014 and 2015 showed that administrative costs averaged $7.9 \%$ of insurance revenue. If the additional life insurance commission revenues in the table had the same administrative cost, they would have cost the firm another $55 \mathrm{RMB}$ for each agent, which we deduct from the return to the firm and total return columns. ${ }^{24}$ This calculation suggests that $63 \%$ of the total return from the new non-linear incentive system went to the firm.

Another way to assess the value of the new incentives on the firm is to examine how the stock market responded to the January $1^{\text {st }}, 2015$ changes. Figure A6 displays the share price of the firm (panel A) and of its share price relative to the share price of its major competitor in the insurance market (panel B) from 200 days before the introduction date to 200 days after the introduction date. Both share prices are scaled to be 1 on the day of the reform to better preserve the identity of the firm. The figure shows a marked jump in the absolute and relative share price in the narrow interval surrounding the introduction of the new compensation scheme. As we know of nothing else that happened to the firm around that time period to produce the marked jump in share price, the results provide suggestive evidence that the market valued the new system as improving net future revenues on the order of $15 \%$ of the value of the firm.

To get a full welfare accounting of the division of the net benefits would require some deduction from the workers to take account of the cost of additional time, effort, and learning to make the new system work for them, which would require an assessment of their non-pecuniary preferences about which we have no information. The turnover data show that workers made a

\footnotetext{
24 The 55 RMB could be higher if the firm had additional implementation costs and could be lower, due to reduced turnover, which almost surely lowered some labor costs. At best it is a plausible magnitude. Even if the expense of the system was double the $55 \mathrm{RMB}$, the benefit from the increased sales commission would dominate the calculation, producing a high total return to the firm.
} 
positive net gain and the revenues less administrative costs and the increased share price shows that the firm gained substantially as well, concerns about gaming the system notwithstanding.

\section{CONCLUSION}

This paper studied the effects of a non-linear compensation scheme on agent productivity and firm profits using a quasi-experiment in which a large insurance firm steepened its non-linear incentive system. Our main finding is that both the firm and the agents eligible for the new compensation scheme benefited significantly even though non-linear incentives created opportunities for workers to game the system, which they did.

Reviewing the literature on the distortionary impacts of non-linear incentive schemes, Lazear and Oyer (2012) raised the question of why agents' gaming non-linear incentives does not undermine those incentives. Our evidence that the large supply response of productive work to firms' steepening incentives far outweighs the distortionary costs of the gaming responses suggests that the answer to the question lies more on the productive work side of the benefit-cost calculation than on the gaming side.

If our findings generalize to the other firms, the key questions that merit attention is why nonlinear incentive systems affect productive behavior so much more than distortionary gaming behavior; and why some firms (such as the one we studied) are slow in introducing or increasing non-linear incentives. This will require more detailed examination of worker responses and of the ways firms choose to introduce or change such systems than our evidence permits. 


\section{REFERENCES}

Ager, P., Bursztyn, L., \& Voth, H. J. (2016). Killer incentives: Status competition and pilot performance during World War II. NBER Working Paper, No. w22992.

Benson, A. (2015). Do agents game their agents' behavior? Evidence from sales managers. Journal of Labor Economics, 33(4), 863-890.

Bryson, Alex, Erling Barth, Harald Dale-Olsen. (2012). Do higher wages come at a price?' Journal of Economic Psychology, 33 (1), 251-263.

Chetty, R. (2012). Bounds on elasticities with optimization frictions: A synthesis of micro and macro evidence on labor supply. Econometrica, 80 (3), 969-1018.

Chung, D. J., Steenburgh, T., \& Sudhir, K. (2013). Do bonuses enhance sales productivity? A dynamic structural analysis of bonus-based compensation plans. Marketing Science, 33(2), $165-$ 187.

DellaVigna, S., \& Pope, D. (2017). What motivates effort? Evidence and expert forecasts. The Review of Economic Studies, 85(2), 1029-1069.

Dobkin, C., Finkelstein, A., Kluender, R., \& Notowidigdo, M. J. (2018). The economic consequences of hospital admissions. American Economic Review, 108(2), 308-52.

Holmstrom, B., \& Milgrom, P. (1991). Multi-task principal-agent analyses: Incentive contracts, asset ownership, and job design. Journal of Law, Economics, \& Organization, 7, 24.

Kaur, S., Kremer, M., \& Mullainathan, S. (2015). Self-control at work. Journal of Political Economy, 123(6), 1227-1277.

Kleven, H. J. (2016). Bunching. Annual Review of Economics, 8, 435-464.

Kleven, H. J., \& Waseem, M. (2013). Using notches to uncover optimization frictions and structural elasticities: Theory and evidence from Pakistan. The Quarterly Journal of Economics, 128(2), 669-723. 
Larkin, I. (2014). The cost of high-powered incentives: Employee gaming in enterprise software sales. Journal of Labor Economics, 32(2), 199-227.

Larkin, I., \& Leider, S. (2012). Incentive schemes, sorting, and behavioral biases of employees: Experimental evidence. American Economic Journal: Microeconomics, 4(2), 184-214.

Lazear, E. P. (2000). Performance pay and productivity. American Economic Review, 90(5), 13461361.

Lazear, Edward P., and Paul Oyer. (2012). Personnel economics. In The Handbook of Organizational Economics, ed. Robert Gibbons and John Roberts. Princeton, NJ: Princeton University Press.

Li T., \& Lu R. (2018). Symbolic awards at work: A regression discontinuity design. Working paper. Misra, S., \& Nair, H. S. (2011). A structural model of sales-force compensation dynamics: Estimation and field implementation. Quantitative Marketing and Economics, 9(3), 211-257.

Oyer, P. (1998). Fiscal year ends and non-linear incentive contracts: The effect on business seasonality. The Quarterly Journal of Economics, 113(1), 149-185.

Oyer, P. (2000). A theory of sales quotas with limited liability and rent sharing. Journal of Labor Economics, 18(3), 405-426.

Saez, E. (2010). Do taxpayers bunch at kink points? American Economic Journal: Economic Policy, 2(3), 180-212.

Shaw, J. D., Gupta, N., \& Delery, J. E. (2000). Empirical organizational-level examinations of agency and collaborative predictions of performance-contingent compensation. Strategic Management Journal, 21(5), 611-623.

Tzioumis, K., \& Gee, M. (2013). Non-linear incentives and mortgage officers' decisions. Journal of Financial Economics, 107(2), 436-453.

Zivin, J. S. G., Kahn, L. B., \& Neidell, M. J. (2019). Incentivizing learning-by-doing: The role of compensation schemes. NBER Working Paper, No. w25799. 


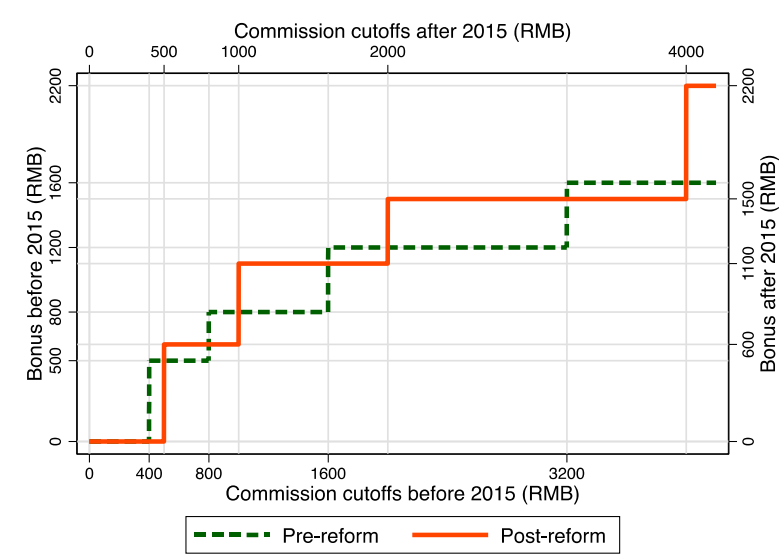

(A) $1^{\text {st }} 3^{\text {rd }}$ tenure months

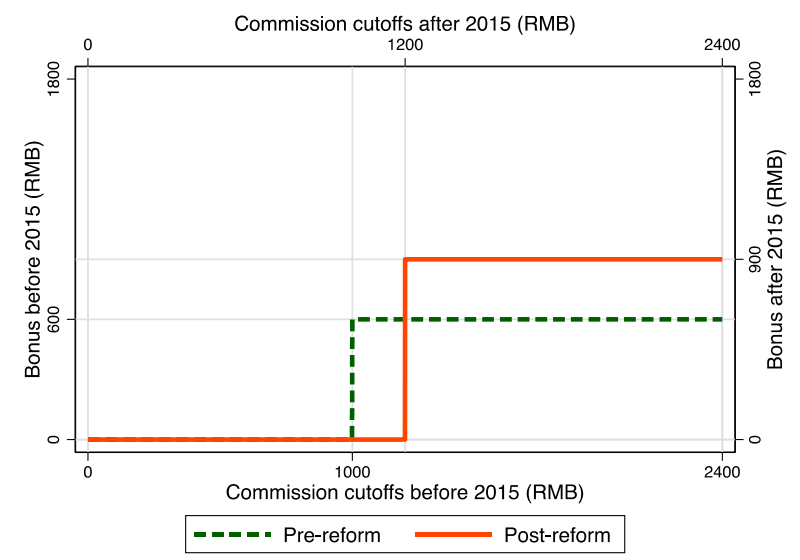

(C) $7^{\text {th }}-9^{\text {th }}$ tenure months

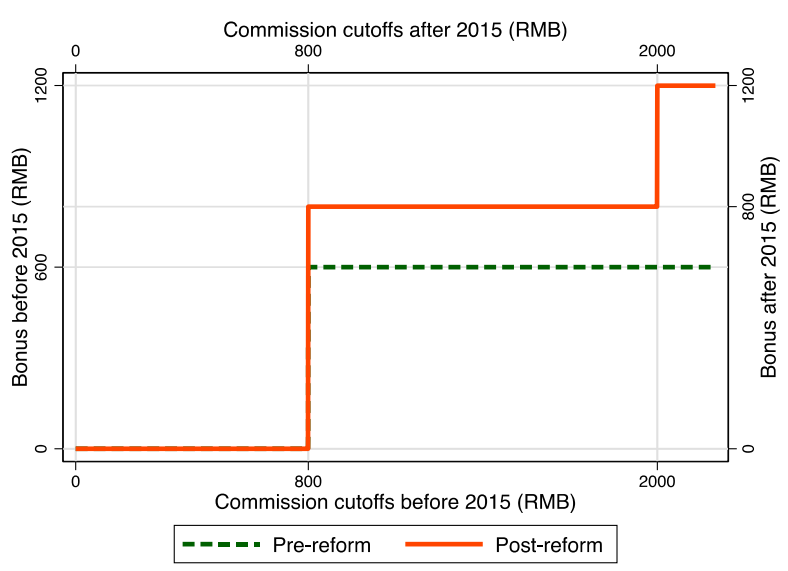

(B) $4^{\text {th }}-6^{\text {th }}$ tenure months

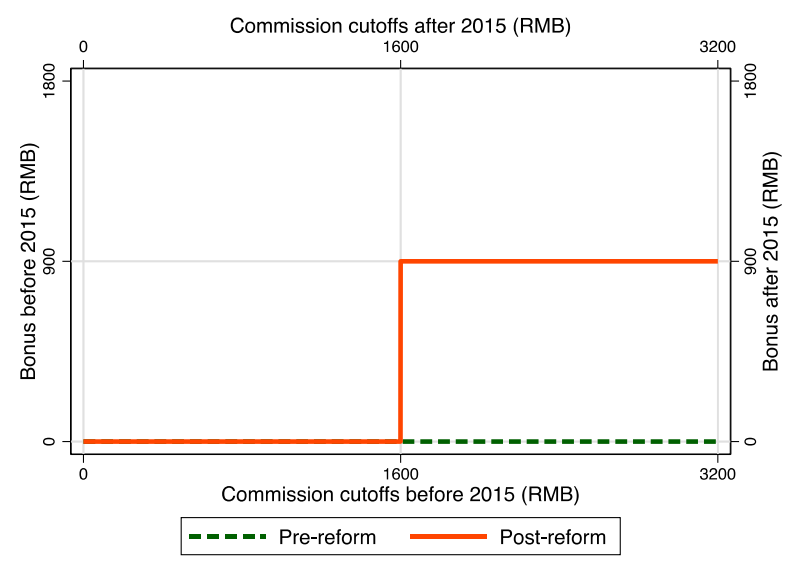

(D) $10^{\text {th }}-12^{\text {th }}$ tenure months

\section{Figure 1: Compensation Schemes for Newly Recruited Agents}

Notes: The figure displays the two compensation schemes for the newly recruited agents before and after January $1^{\text {st }}, 2015$. The green-dash and red-solid lines represent the compensation scheme before and after the reform, respectively. To illustrate the compensation scheme, we take agents in the $1^{\text {st }}-3^{\text {rd }}$ tenure months before 2015 as an example. When their life insurance commission in any months of their $1^{\text {st }}-3^{\text {rd }}$ tenure months reaches 400,800 , 1,600 , or 3,200 RMB, the corresponding bonuses are 500,800,1,200, or 1,600 RMB, respectively. Their income will be $900,1,600,2,800$, and 4,800 RMB, respectively. 


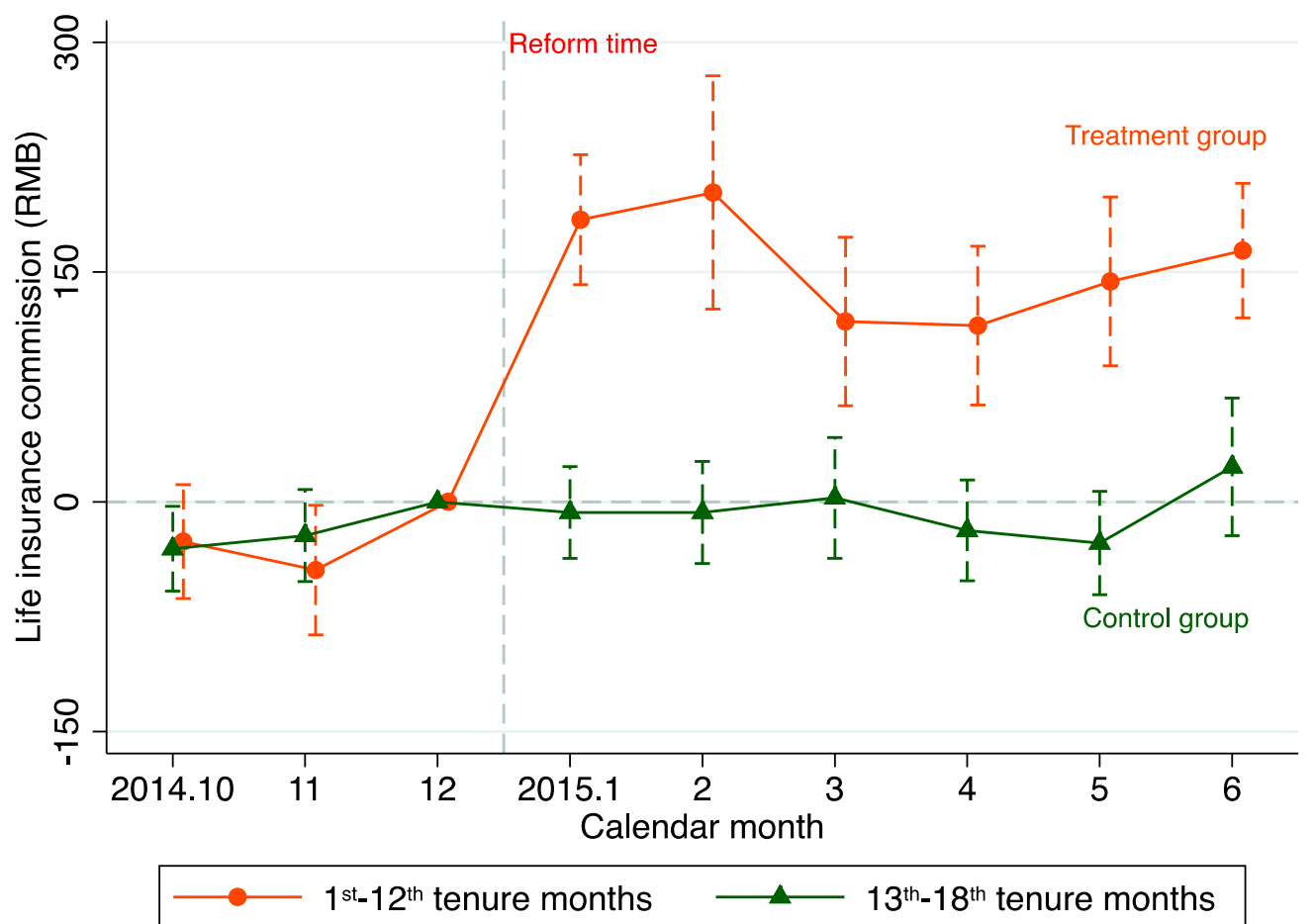

Figure 2: Event Study - Estimated Effect on the Life Insurance Commission

Notes: This figure presents the estimated dynamic response to life insurance commission of the agents. We use the time period from 2014.10 to 2015.06 and plot the average life insurance commission by month for agents in their $1^{\text {st }}-12^{\text {th }}$ and $13^{\text {th }}-18^{\text {th }}$ tenure months, respectively. December 2014 is the reference group (normalized to be zero). The $\mathrm{x}$-axis denotes the calendar months, and the $\mathrm{y}$-axis shows the estimated response to life insurance commission (RMB). 


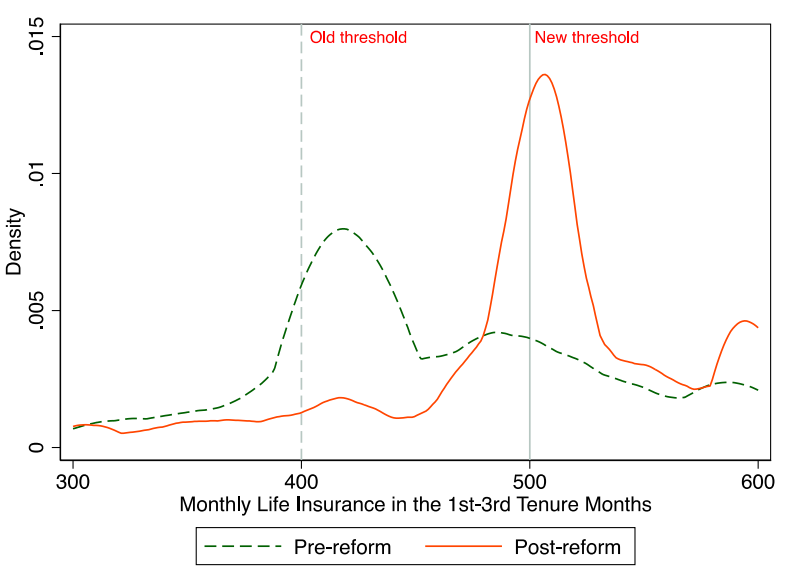

(A) $1^{\text {st }}-3^{\text {rd }}$ tenure months

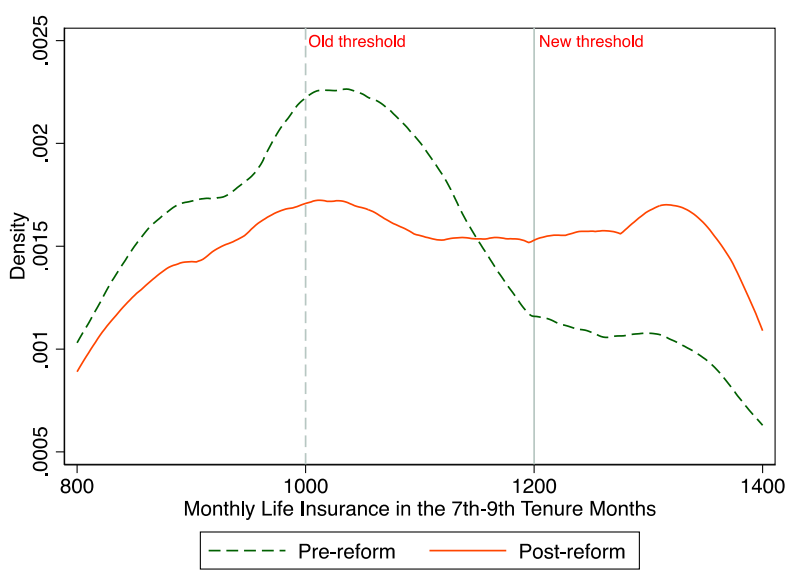

(C) $7^{\text {th }}-9^{\text {th }}$ tenure months

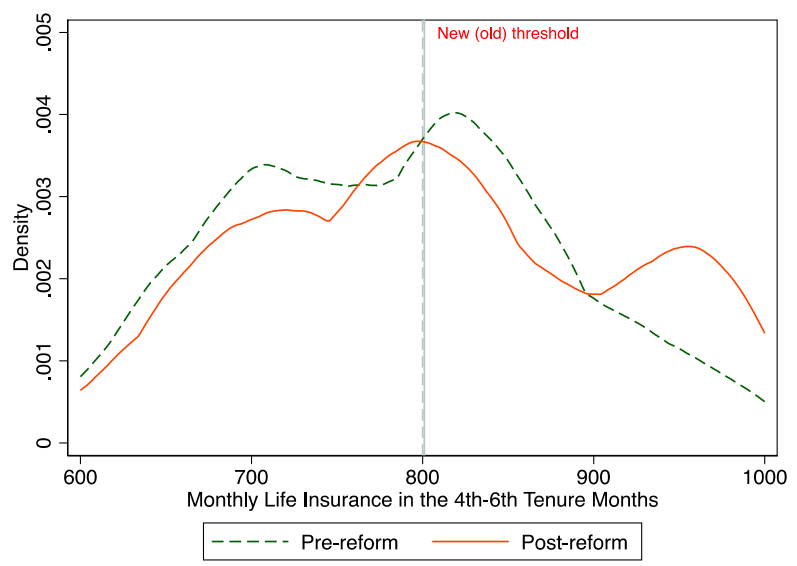

(B) $4^{\text {th }}-6^{\text {th }}$ tenure months

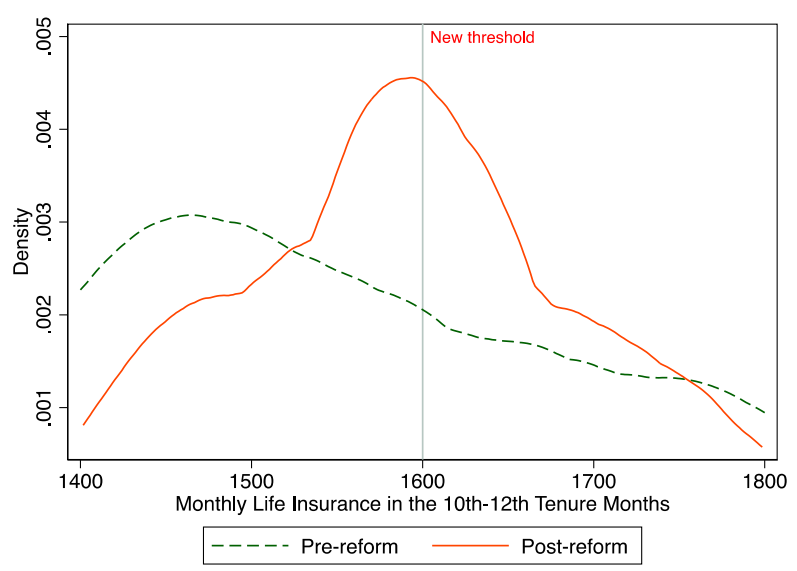

(D) $10^{\text {th }}-12^{\text {th }}$ tenure months

\section{Figure 3: Distributions of Life Insurance Commission around the Thresholds}

Notes: The figure presents the distributions of life insurance commission around the thresholds of the old (green dash lines) and new (red solid lines) compensation schemes. For the $1^{\text {st }}-3^{\text {rd }}$ tenure months, we select the distribution of life insurance commission around the lowest commission threshold of the old and new compensation schemes, as can be seen in panel (A). The distributions around other levels of commission thresholds for the $1^{\text {st }}-3^{\text {rd }}$ tenure months are displayed in Figure A3. In panel (B) we plot the distribution of life insurance commission around the lowest commission threshold (800 RMB). The distribution around the top commission threshold for the $4^{\text {th }}-6^{\text {th }}$ tenure months is drawn in Figure A4. Panels (C) and (D) show the distributions for the $7^{\text {th }}-9^{\text {th }}$ and $10^{\text {th }}-12^{\text {th }}$ tenure months, respectively. These figures are (Epanechnikov) kernel density plots. 


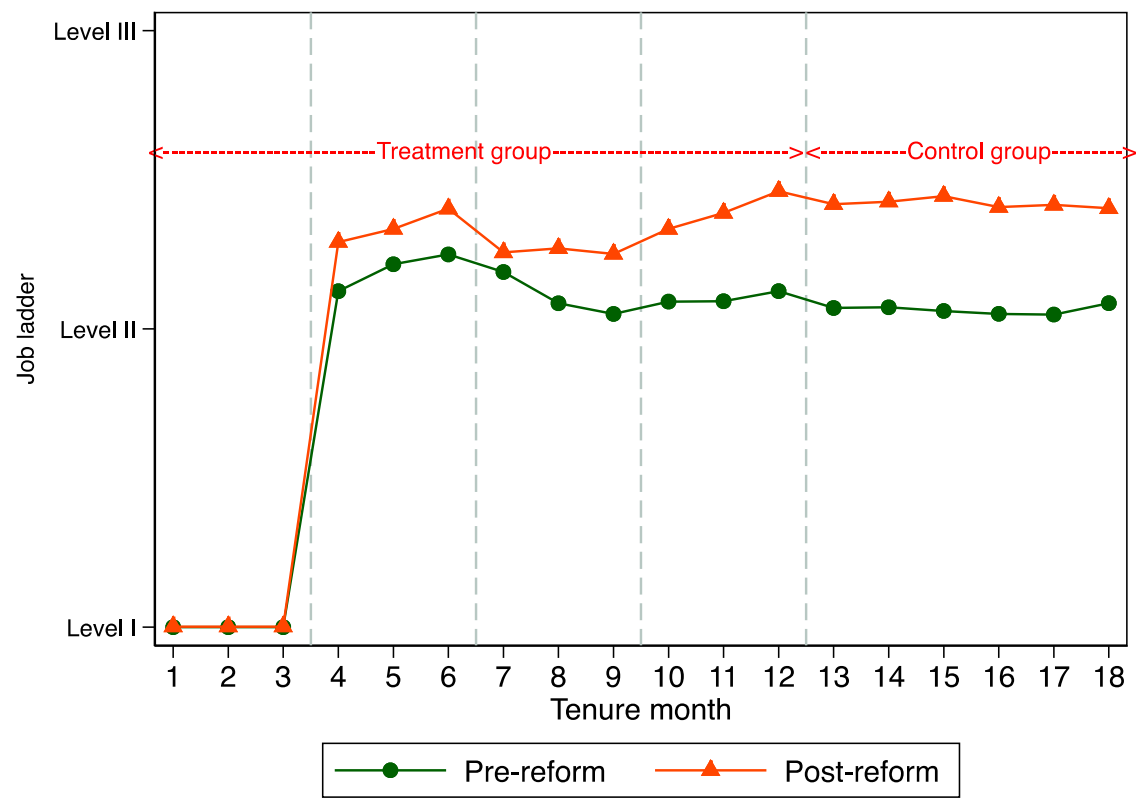

(A) Job ladder by tenure month

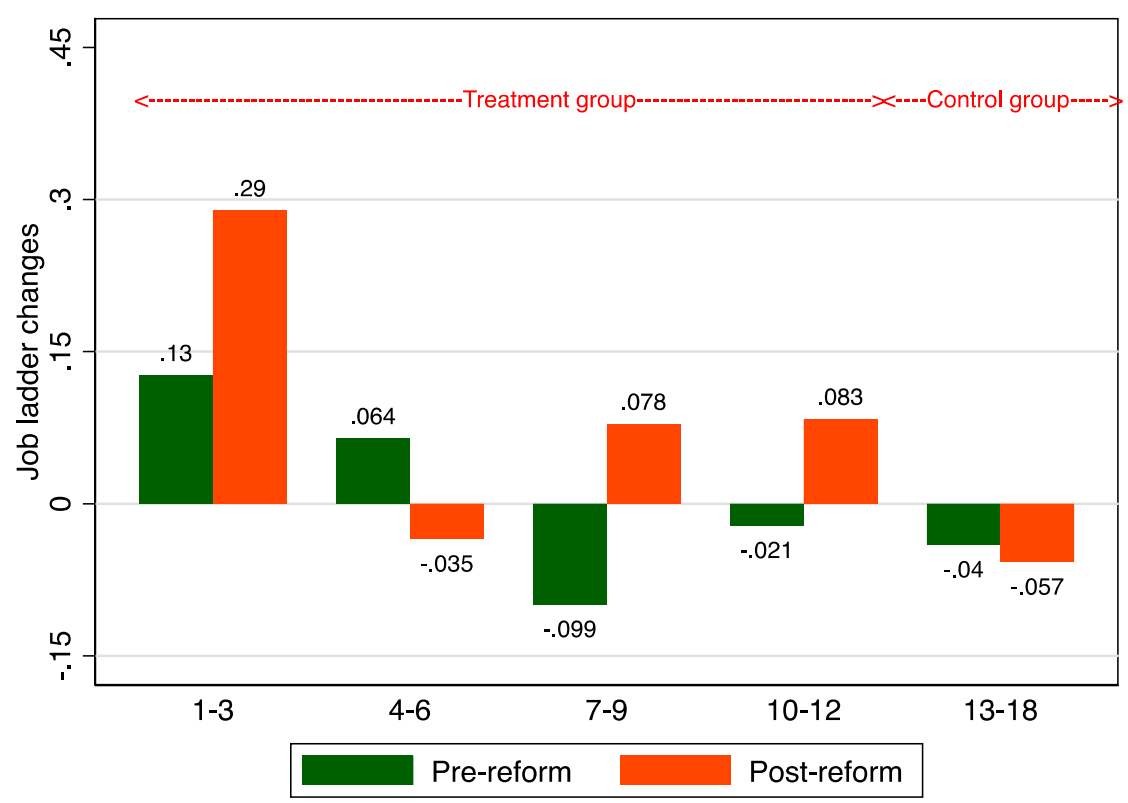

(B) Job ladder changes by tenure month

\section{Figure 4: Changes in Job Ladders}

Notes: Panel (A) of this figure displays the evolution of job ladders by tenure month. The green-circle line denotes the agents who joined the firm between January and June 2013. The red-triangle line represents the agents who joined the firm between January and June 2015. Panel (B) presents job ladder changes for each tenure-month group. The left (green) and right (red) bar in each tenure-month group denotes the agents who joined the firm between January and June 2013 and between January and June 2015, respectively. We calculate the numbers by taking the difference between job ladders at the start of next season and this season. For instance, to derive job ladder changes for $4^{\text {th }}-6^{\text {th }}$ tenure-month group, we take the difference between job ladders at the start of July and start of April. 


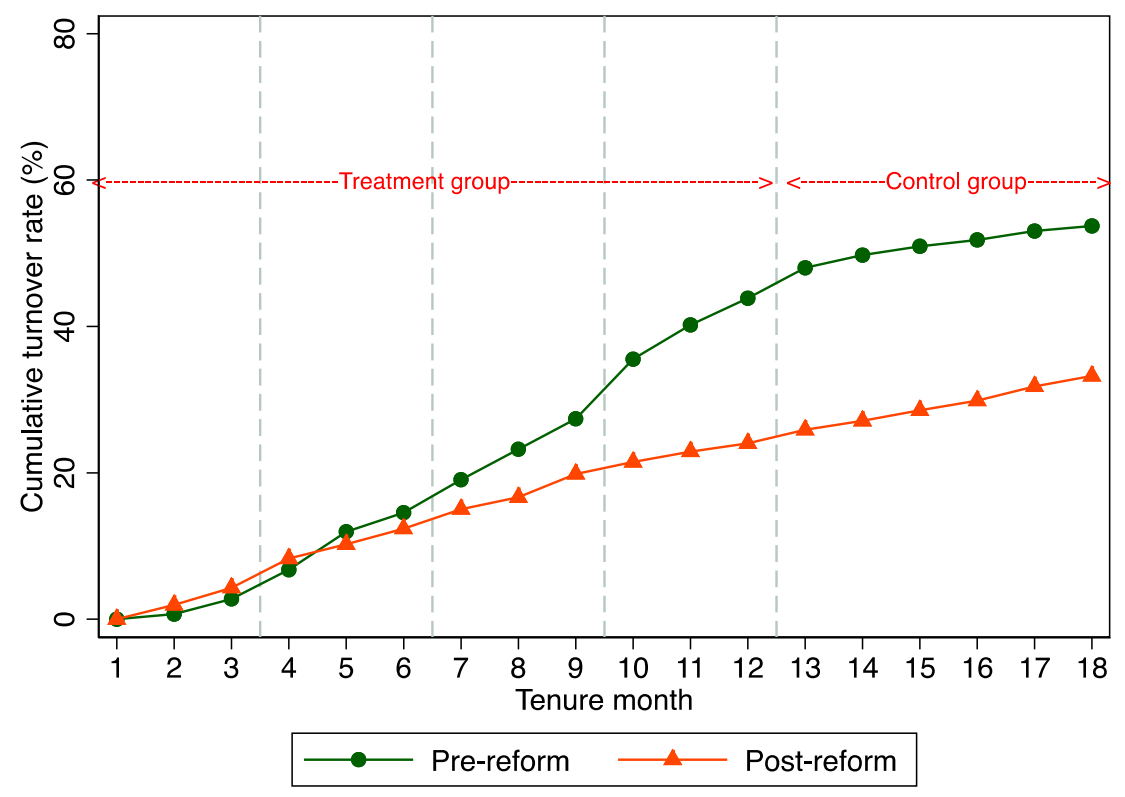

(A) Cumulative turnover rate over tenure month

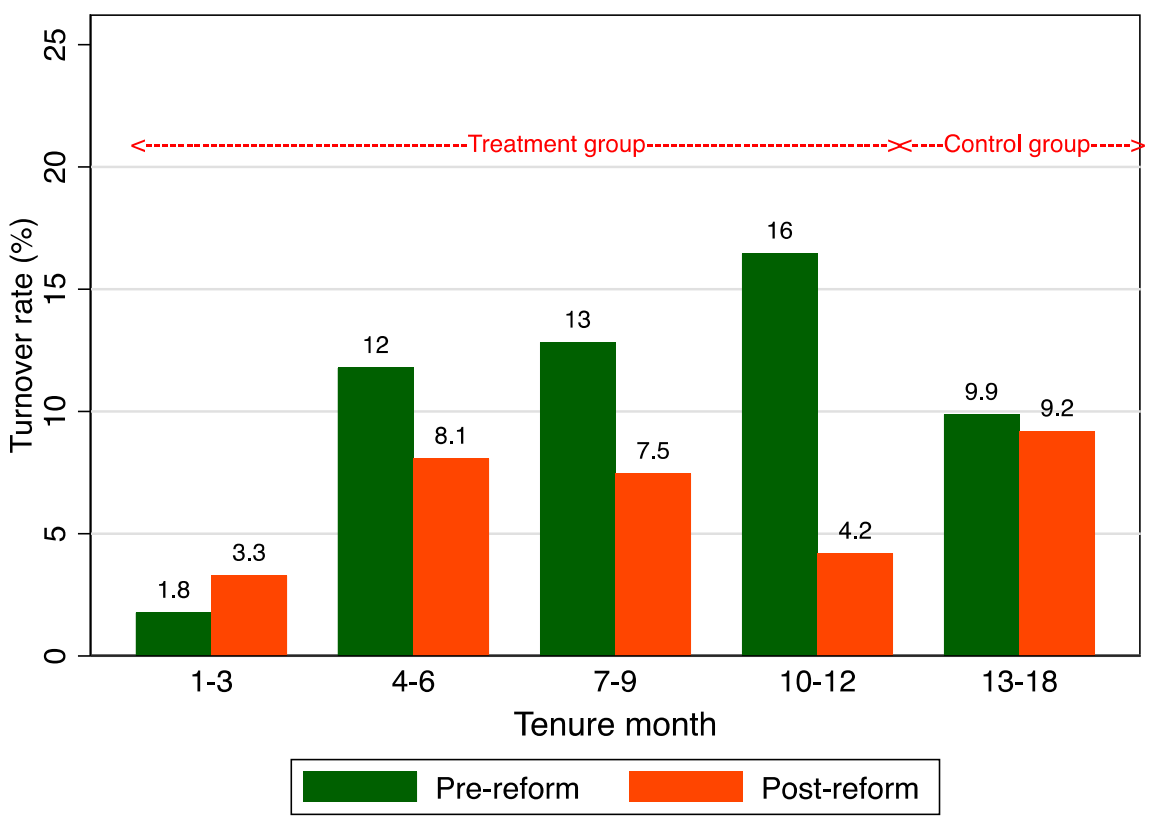

(B) Turnover rate by tenure-month group

Figure 5: Impact of the Reform on Turnover Rate

Notes: Panel (A) of this figure displays how the turnover rate is cumulated by tenure month. The green-circle line denotes the agents who joined the firm between January and June 2013. The red-triangle line represents the agents who joined the firm between January and June 2015. Panel (B) presents the turnover rate for each tenuremonth group. The left (green) and right (red) bar in each tenure-month group denotes the agents who joined the firm between January and June 2013 and between January and June 2015, respectively. We calculate the numbers by taking the difference between cumulative turnover rate at the end and start of each season. For instance, to derive the turnover rate for the $4^{\text {th }}-6^{\text {th }}$ tenure-month group, we take the difference between cumulative turnover rate at the end of June and start of April. 
Table 1: Summary Statistics of the Analysis Sample

\begin{tabular}{lccccc}
\hline & $(1)$ & $(2)$ & $(3)$ & $(4)$ & $(5)$ \\
VARIABLES & Obs. & Mean & SD & Min & Max \\
\hline Panel A: Job Performance & & & & & \\
Life insurance commission (RMB) & 13,319 & 347.87 & $1,310.48$ & 0.00 & $39,195.60$ \\
Other insurance commission (RMB) & 13,319 & 64.18 & 474.69 & 0.00 & $23,418.80$ \\
Withdrawn commission (RMB) & 13,319 & 50.98 & 546.55 & 0.00 & $32,000.00$ \\
Bonus (RMB) & 13,319 & 148.88 & 388.06 & 0.00 & $4,000.00$ \\
Tenure months & 13,319 & 6.91 & 4.94 & 1.00 & 18.00 \\
Panel B: Personal Characteristics & & & & & \\
Female (=1) & 2,945 & 0.66 & 0.47 & 0.00 & 1.00 \\
Urban status (=1) & 2,945 & 0.50 & 0.50 & 0.00 & 1.00 \\
Age (years) & 2,945 & 35.00 & 7.98 & 19.25 & 57.50 \\
Polytechnic-school graduate $(=1)$ & 2,945 & 0.39 & 0.49 & 0.00 & 1.00 \\
High-school graduate (=1) & 2,945 & 0.20 & 0.40 & 0.00 & 1.00 \\
College graduate $(=1)$ & 2,945 & 0.32 & 0.47 & 0.00 & 1.00 \\
Bachelor and the above $(=1)$ & 2,945 & 0.09 & 0.28 & 0.00 & 1.00 \\
\hline
\end{tabular}

Notes: This table provides descriptive statistics for our main analysis sample. The sample period is from October 2014 to March 2015. In the sample, we keep the agents who are in their $1^{\text {st }}-18^{\text {th }}$ tenure months during the time period. In panel (A), each observation denotes an agent-month cell. Tenure months is the length of stay (in months) in the firm in each calendar month. In panel (B), each observation denotes an agent cell. Female is an indicator of being female. Urban status is an indicator of coming from urban areas. Age is the age in years. Education levels are divided into four categories, including polytechnic-school, high-school, and college graduates and bachelors and the above. 
Table 2: Impacts of the New Incentive System on Insurance Commission

\begin{tabular}{|c|c|c|c|c|c|}
\hline \multirow[b]{3}{*}{ Tenure months } & \multicolumn{4}{|c|}{ Treatment group } & \multirow{3}{*}{$\begin{array}{c}\text { Control group } \\
(5) \\
13^{\text {th }}-18^{\text {th }}\end{array}$} \\
\hline & (1) & (2) & (3) & (4) & \\
\hline & $1^{s t}-3^{r d}$ & $4^{t h}-6^{t h}$ & $7^{\text {th }}-9^{\text {th }}$ & $10^{t h}-12^{t h}$ & \\
\hline & \multicolumn{5}{|c|}{ Panel A: Life insurance commission (RMB) } \\
\hline Baseline sample mean (RMB) & 766.5 & 328.3 & 282.2 & 271.9 & 256.6 \\
\hline Baseline estimates & $\begin{array}{c}236.7^{* * * *} \\
(41.2)\end{array}$ & $\begin{array}{c}169.2 * * * \\
(49.6)\end{array}$ & $\begin{array}{c}102.1^{* * * *} \\
(36.6)\end{array}$ & $\begin{array}{c}128.2^{* *} \\
(61.7)\end{array}$ & $\begin{array}{c}-9.9 \\
(34.2)\end{array}$ \\
\hline \multirow[t]{2}{*}{ Estimates with agent $\mathrm{FE}$} & $\begin{array}{c}294.8 * * * \\
(43.5)\end{array}$ & $\begin{array}{c}133.2 * * * \\
(48.8)\end{array}$ & $\begin{array}{c}119.0 * * * \\
(37.6)\end{array}$ & $\begin{array}{c}145.9 * * * \\
(53.2)\end{array}$ & $\begin{array}{c}-1.4 \\
(36.5)\end{array}$ \\
\hline & \multicolumn{5}{|c|}{ Panel B: Other insurance commission (RMB) } \\
\hline Baseline sample mean (RMB) & 119.6 & 57.3 & 48.3 & 42.3 & 56.7 \\
\hline Baseline estimates & $\begin{array}{c}-33.0^{* * *} \\
(9.8)\end{array}$ & $\begin{array}{c}-16.9 * * \\
(8.3)\end{array}$ & $\begin{array}{c}-33.6^{* *} \\
(14.8)\end{array}$ & $\begin{array}{l}-24.6 \\
(15.3)\end{array}$ & $\begin{array}{l}-4.2 \\
(3.6)\end{array}$ \\
\hline \multirow[t]{2}{*}{ Estimates with agent $\mathrm{FE}$} & $\begin{array}{c}-25.4^{* *} \\
(10.2)\end{array}$ & $\begin{array}{c}-19.6^{* *} \\
(8.7)\end{array}$ & $\begin{array}{l}-25.1 \\
(18.2)\end{array}$ & $\begin{array}{c}-20.6^{* *} \\
(8.7)\end{array}$ & $\begin{array}{l}-2.9 \\
(3.7)\end{array}$ \\
\hline & \multicolumn{5}{|c|}{ Panel C: Withdrawn insurance commission (RMB) } \\
\hline Baseline sample mean (RMB) & 64.5 & 44.2 & 39.8 & 44.3 & 39.6 \\
\hline Baseline estimates & $\begin{array}{c}52.4^{* * *} \\
(13.3)\end{array}$ & $\begin{array}{c}45.4 * * * \\
(17.1)\end{array}$ & $\begin{array}{c}76.2 * * * \\
(20.2)\end{array}$ & $\begin{array}{c}46.7 * * \\
(22.2)\end{array}$ & $\begin{array}{c}1.6 \\
(1.4)\end{array}$ \\
\hline Estimates with agent $\mathrm{FE}$ & $\begin{array}{c}61.9^{* * *} * \\
(14.3)\end{array}$ & $\begin{array}{c}42.0 * * \\
(17.8)\end{array}$ & $\begin{array}{c}74.8 * * * \\
(21.4)\end{array}$ & $\begin{array}{c}56.6^{* *} \\
(25.1)\end{array}$ & $\begin{array}{c}1.9 \\
(1.6)\end{array}$ \\
\hline No. of agents & 1,710 & 1,564 & 953 & 597 & 693 \\
\hline Observations & 4,190 & 3,480 & 2,011 & 1,271 & 2,367 \\
\hline
\end{tabular}

Notes: Panels (A), (B), and (C) of this table summarize how life, other, and withdrawn insurance commission respond to the new compensation scheme, respectively. The regression sample is restricted to a narrow time window from October 2014 to March 2015, i.e., three months before and after the reform. Each coefficient denotes an independent regression. The leftmost column describes the specification. In baseline estimates, we control agent's demographic characteristics, tenure month fixed effects, and calendar month linear trend following Equation (2). Demographic characteristics include female dummy, urban dummy, education level indicators, and age. For estimates with agent FE, we further control agent fixed effects in Equation (2). Standard errors are reported in parentheses under the coefficient estimates, and ***,**, and * denote statistical significance at the $1 \%, 5 \%$, and $10 \%$ levels. 
Table 3: Impacts of New Incentive System on Promotion/Demotion and Turnover

\begin{tabular}{|c|c|c|c|c|}
\hline \multirow[b]{2}{*}{ Variables } & $(1)$ & $(2)$ & (3) & $(4)$ \\
\hline & \multicolumn{2}{|c|}{ Job ladder changes } & \multicolumn{2}{|c|}{ Leave the firm $(=1)$} \\
\hline Baseline sample mean & \multicolumn{2}{|c|}{0.01} & \multicolumn{2}{|c|}{0.05} \\
\hline Post-reform & $\begin{array}{l}-0.098 \\
(0.112)\end{array}$ & $\begin{array}{l}-0.101 \\
(0.112)\end{array}$ & $\begin{array}{c}0.003 \\
(0.004)\end{array}$ & $\begin{array}{c}0.003 \\
(0.004)\end{array}$ \\
\hline Post-reform $* 1^{\text {st }}-12^{\text {th }}$ tenure months & $\begin{array}{c}0.355^{* * *} \\
(0.130)\end{array}$ & & $\begin{array}{c}-0.022 * * * \\
(0.005)\end{array}$ & \\
\hline Post-reform $* 1^{\text {st }}-3^{\text {rd }}$ tenure months & & $\begin{array}{c}0.096 \\
(0.112)\end{array}$ & & $\begin{array}{c}0.008 \\
(0.007)\end{array}$ \\
\hline Post-reform $* 4^{\text {th }}-6^{\text {th }}$ tenure months & & $\begin{array}{c}0.429 * * * \\
(0.147)\end{array}$ & & $\begin{array}{c}-0.019 * * \\
(0.008)\end{array}$ \\
\hline Post-reform $* 7^{\text {th }}-9^{\text {th }}$ tenure months & & $\begin{array}{c}0.238 \\
(0.167)\end{array}$ & & $\begin{array}{c}-0.041 * * * \\
(0.009)\end{array}$ \\
\hline Post-reform $* 10^{\text {th }}-12^{\text {th }}$ tenure months & & $\begin{array}{c}0.711 * * * \\
(0.221)\end{array}$ & & $\begin{array}{c}-0.049 * * * \\
(0.009)\end{array}$ \\
\hline Observations & 21,652 & 21,652 & 21,652 & 21,652 \\
\hline R-squared & 0.013 & 0.016 & 0.013 & 0.016 \\
\hline No. of agents & 1559 & 1559 & 1559 & 1559 \\
\hline Tenure month FE & $\mathrm{x}$ & $\mathrm{x}$ & $\mathrm{x}$ & $\mathrm{x}$ \\
\hline Calendar month FE & $\mathrm{x}$ & $\mathrm{x}$ & $\mathrm{x}$ & $\mathrm{x}$ \\
\hline Demographic controls & $\mathrm{x}$ & $\mathrm{x}$ & $\mathrm{x}$ & $\mathrm{x}$ \\
\hline
\end{tabular}

Notes: Columns (1) and (2) of this table display the estimates on the effects of the new compensation scheme on job ladder changes. The treatment group consists of the agents who were recruited between January and June 2015. The control group includes agents who were recruited between January and June 2013. The dependent variables in columns (1)-(2) are a measure of job ladder changes, which take on three values, i.e., -1 (demotion), 0 (unchanged), and 1 (promotion). Regressions in columns (1) and (2) are estimated by ordered logistic models. Controls and fixed effects are the same as in Equation (3). We also tried to estimate an OLS model and the results are consistent. The reference group includes the agents who are in their $13^{\text {th }}-18^{\text {th }}$ tenure months. Columns (3) and (4) report the estimates on the effects of the new compensation scheme on turnover. The treatment and control groups are the same as in columns (1) and (2). The dependent variables in columns (3)-(4) are a binary variable indicating whether agents leave the firm or not. Estimates in columns (3) and (4) are based on Equation (3). The reference group includes the agents who are in their $13^{\text {th }}-18^{\text {th }}$ tenure months. Demographic control variables include female dummy, urban dummy, education level indicators, and age. All standard errors are clustered at the agent level. Standard errors are reported in parentheses under the coefficient estimates, and ***, $* *$, and * denote statistical significance at the $1 \%, 5 \%$, and $10 \%$ levels, respectively. 
Table 4: Distribution of Net Benefits from the New Incentive System

\begin{tabular}{cccc}
\hline & $\begin{array}{c}\text { Return to Agents } \\
(\mathrm{RMB})\end{array}$ & $\begin{array}{c}\text { Return to Firm } \\
\text { (RMB) }\end{array}$ & $\begin{array}{c}\text { Total Return } \\
\text { (RMB) }\end{array}$ \\
\hline Life Insurance Commission & 232.1 & 696.2 & 928.2 \\
Other Insurance Commission & -22.7 & -68.0 & -90.7 \\
Withdrawn Commission & -58.8 & -176.5 & -235.3 \\
Bonus & 67.1 & -67.1 & 0 \\
Return from reduced turnover & 37.3 & 99.5 & 136.7 \\
Estimated Administrative Cost of & 0 & -59.1 & -59.1 \\
Changes & & 424.9 & 679.8 \\
\hline Total Return & 254.9 &
\end{tabular}

Notes: This table reports the distribution of net benefits from the non-linear incentive system between agents and the firm. The return to the agents from the increased life insurance commission is computed based on the estimates in panels (A) and (C) of Table 2. Specifically, we take the average of the effect on the net life insurance commission in panels (A) of Table 2 and plus the average withdrawn commission derived from panels (C) of Table 2. The return to the firm from the increased life insurance sales is computed by the following procedures. We first divide the return to the agents by the commission rate $(15 \%)$ and minus the return to the agents and average claim cost ( $40 \%$ of the insurance premium). The return from other insurance and withdrawn commission is computed similarly based on the estimates in panels (B) and (C) of Table 2. Average increased bonuses are calculated based on the estimates in Table A2. Based on the firm's annual report, we know that the cost of implementing the changes (or administration costs) occupies about $8 \%$ of total insurance premium revenue. Therefore, we compute the administration costs by summing up the commission in column (3) together with the benefits from reduced turnover times $8 \%$. The total returns are the summation of the items in all the other rows. 


\section{Appendix A}

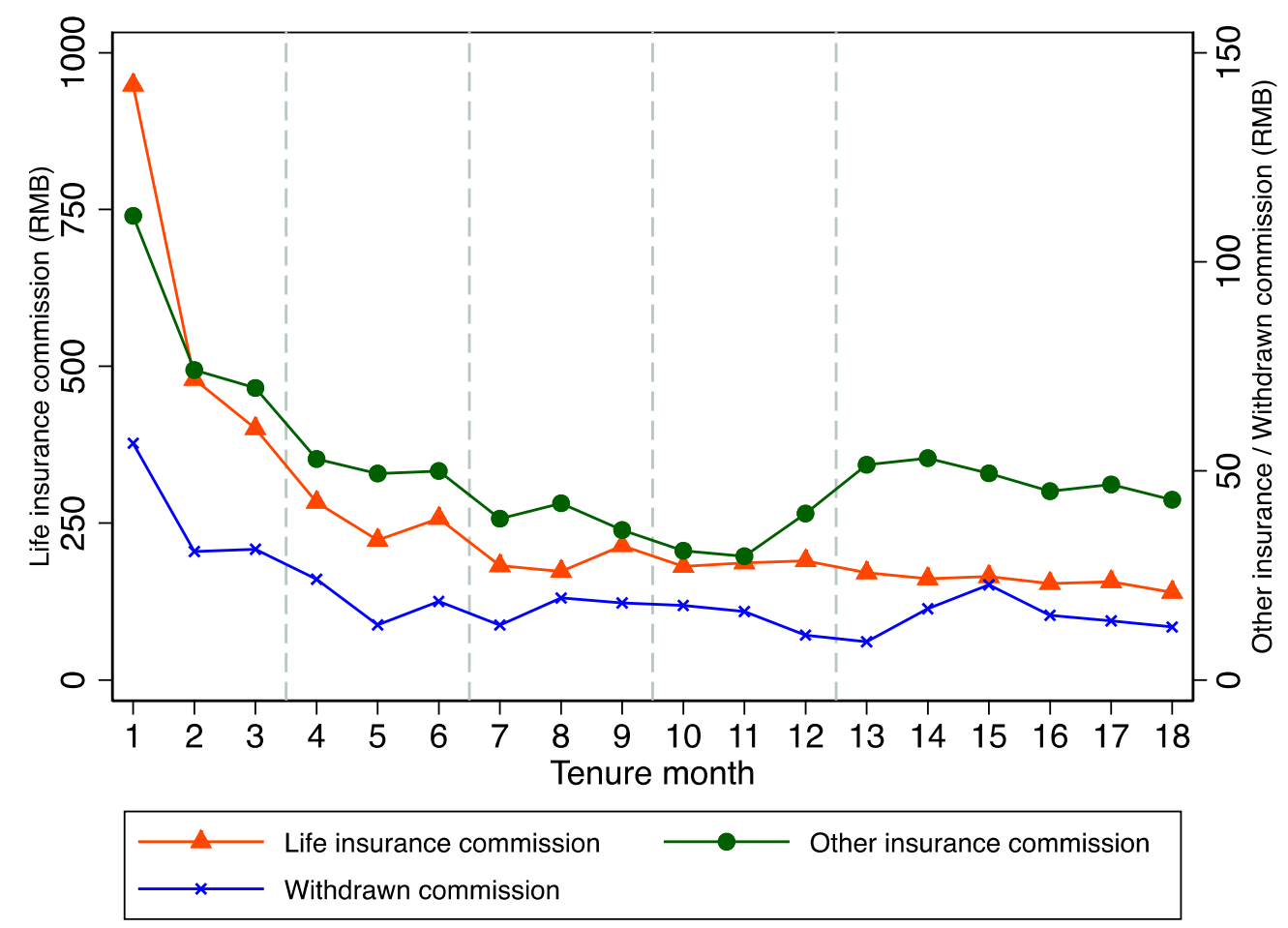

Figure A1: The Productivity of Sales Agents in the $1^{\text {st }}-18^{\text {th }}$ Tenure Months

Notes: The figure displays the monthly performance of sales agents in their $1^{\text {st }}-18^{\text {th }}$ tenure months before the new compensation scheme's initiation. The red-triangle, green-circle, and blue-x lines present the fluctuations of life insurance, other insurance, and withdrawn commission by tenure month, respectively. 


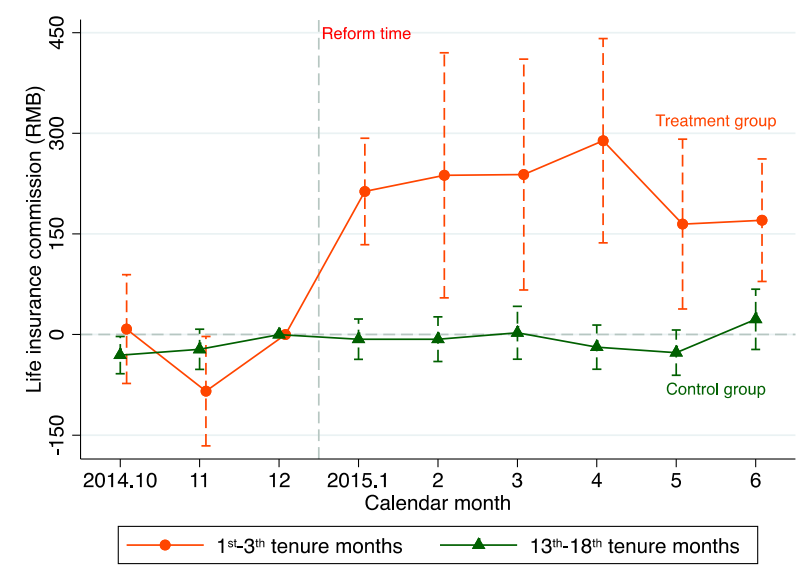

(A) $1^{\text {st }}-3^{\text {rd }}$ tenure months

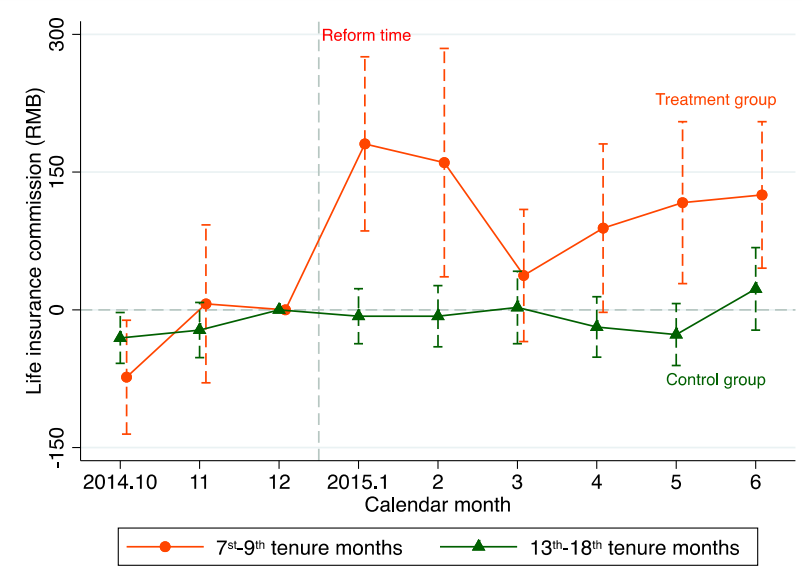

(C) $7^{\text {th }}-9^{\text {th }}$ tenure months

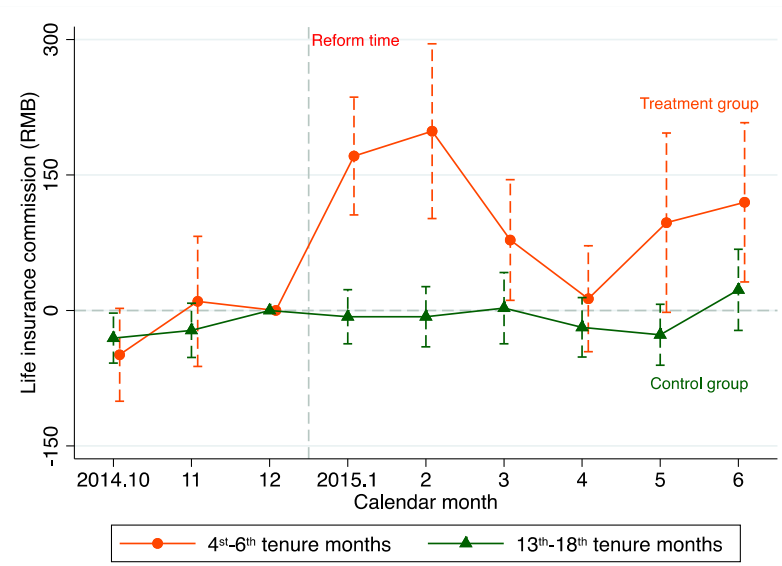

(B) $4^{\text {th }}-6^{\text {th }}$ tenure months

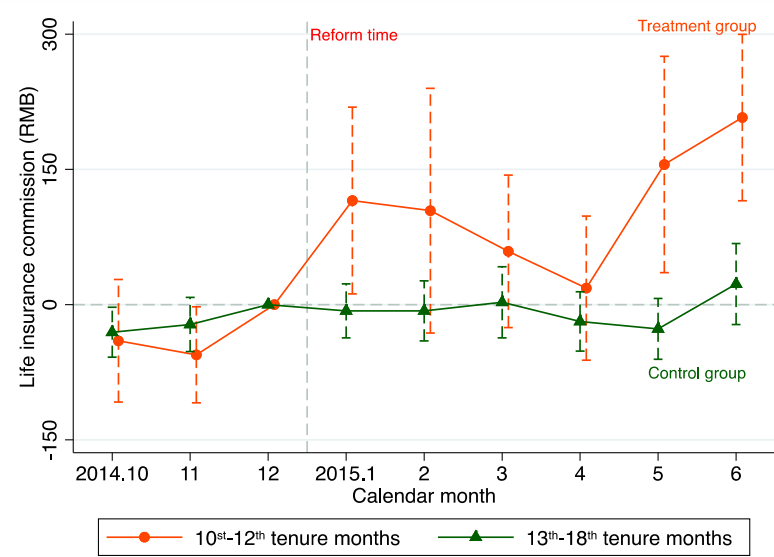

(D) $10^{\text {th }}-12^{\text {th }}$ tenure months

Figure A2: Event Study by Tenure-month Group

Notes: This figure presents the estimated dynamic response to life insurance commission of the agents for each tenure-month group. We use the time period from 2014.10 to 2015.6 and plot the average life insurance commission by month for agents in their $1^{\text {st }}-3^{\text {rd }}, 4^{\text {th }}-6^{\text {th }}, 7^{\text {th }}-9^{\text {th }}, 10^{\text {th }}-12^{\text {th }}$, and $13^{\text {th }}-18^{\text {th }}$ tenure months, respectively. December 2014 is the reference group (normalized to be zero). The $\mathrm{x}$-axis denotes the calendar months, and the $\mathrm{y}$-axis shows the estimated response to life insurance commission (RMB). 


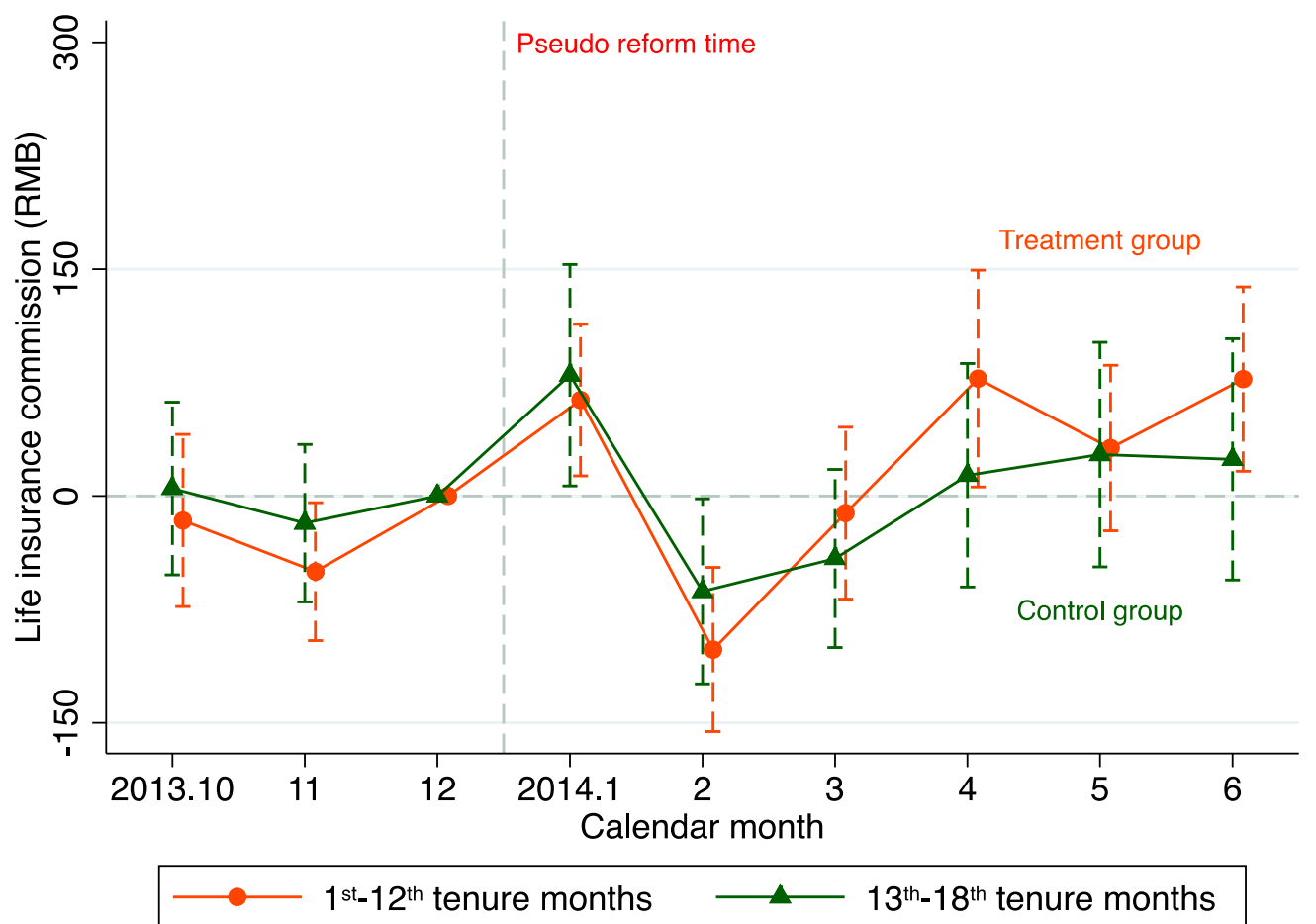

Figure A3: Event Study - Estimated Placebo Effect on the Life Insurance Commission

Notes: This figure plots the estimated placebo dynamic response to life insurance commission of the agents. In this figure, we assume the reform initiated in January 2014. We use the time period from 2013.10 to 2014.6 and repeat the plots in Figure 2. December 2013 is the reference group (normalized to be zero). The $\mathrm{x}$-axis denotes the calendar months, and the y-axis shows the estimated response to life insurance commission (RMB). 


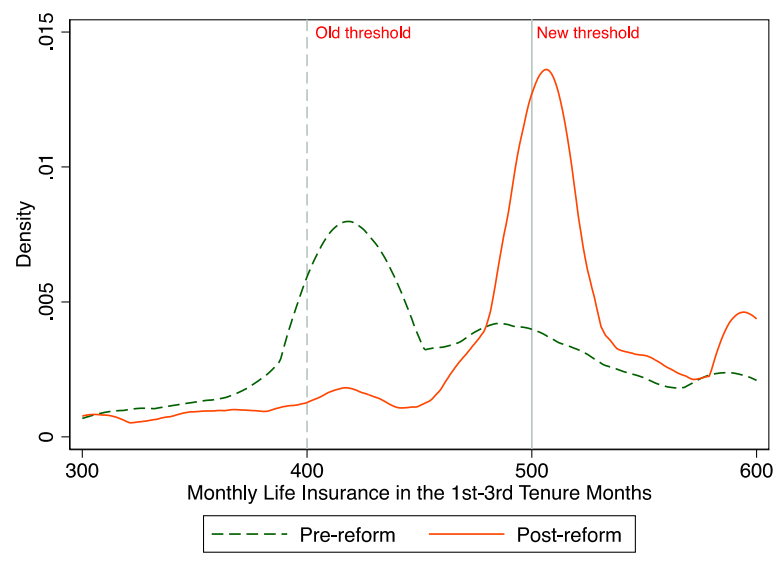

(A) The first level commission threshold

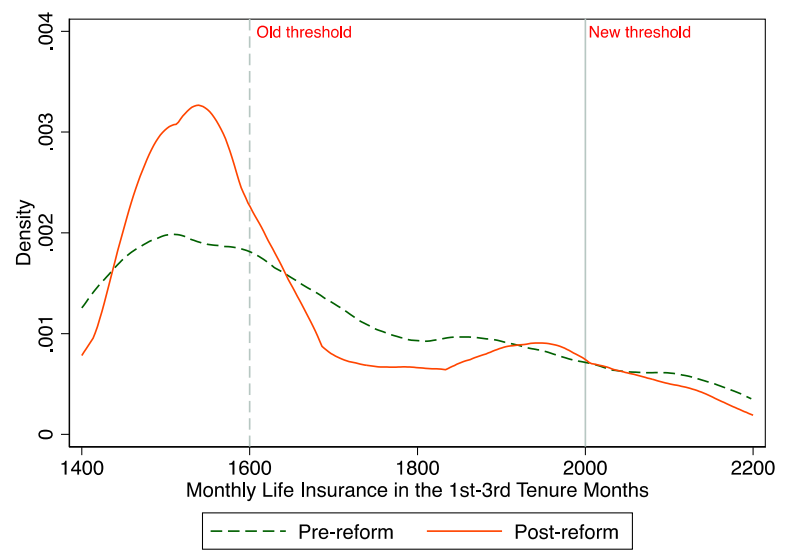

(C) The third level commission threshold

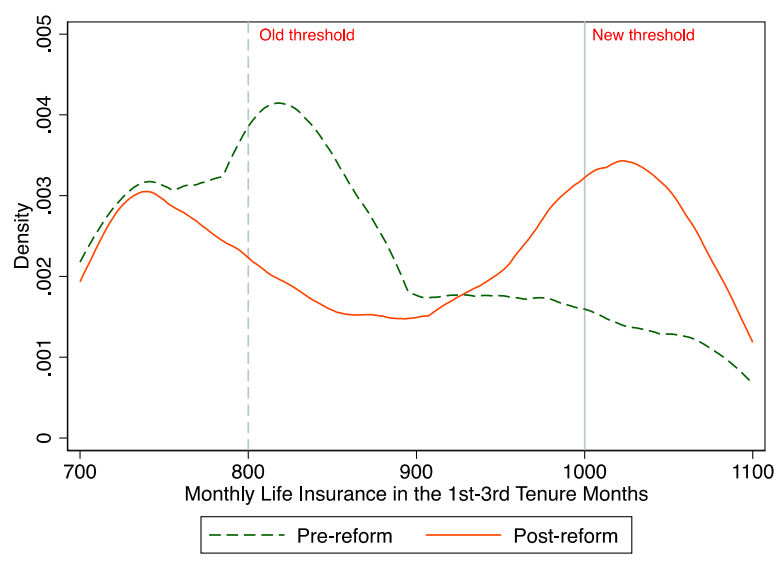

(B) The second level commission threshold

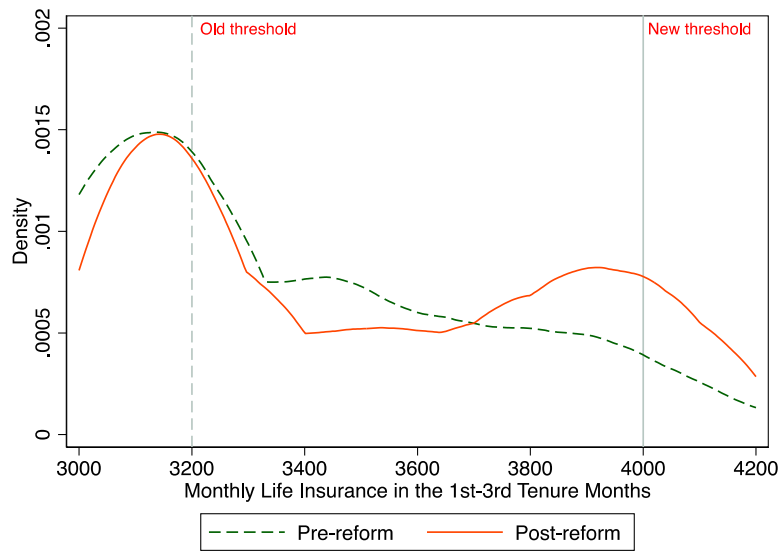

(D) The fourth level commission threshold

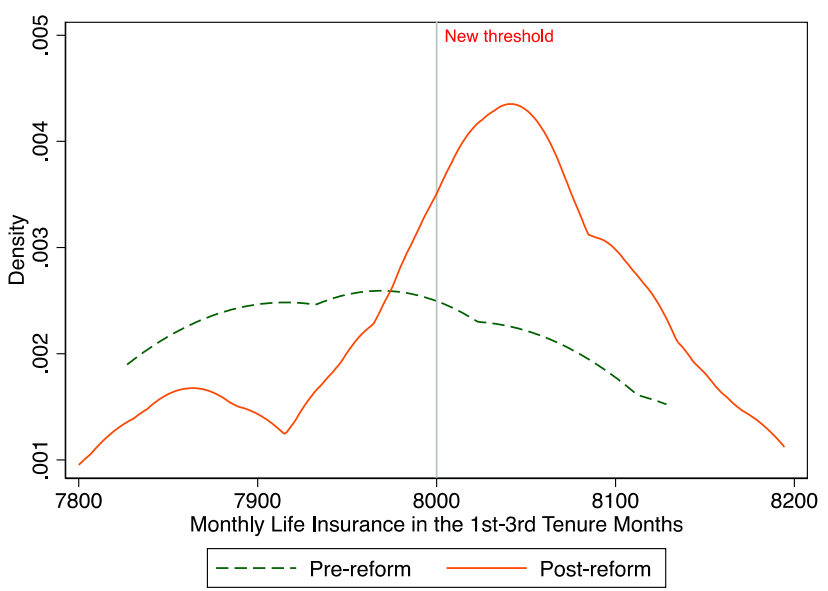

(E) The fifth level commission threshold

\section{Figure A4: Distributions of Life Insurance Commission around Thresholds for $1^{\text {st }}-3^{\text {rd }}$} Tenure Months

Notes: The figure plots the distributions of life insurance commission around the commission thresholds of the old (green dash lines) and new (red solid lines) compensation schemes for the $1^{\text {st }} 3^{\text {rd }}$ tenure months. Panels (A)(E) present from the lowest to the highest commission threshold, respectively. These figures are (Epanechnikov) kernel density plots. 


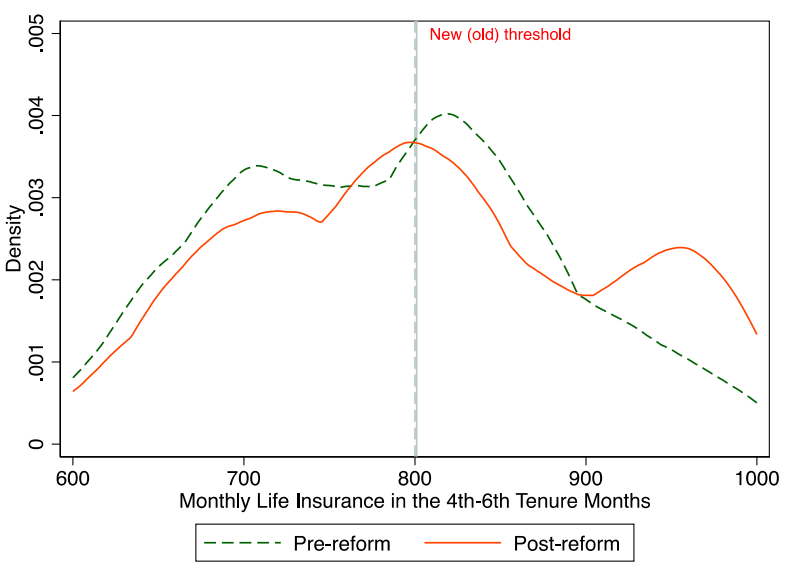

(A) The first level commission threshold

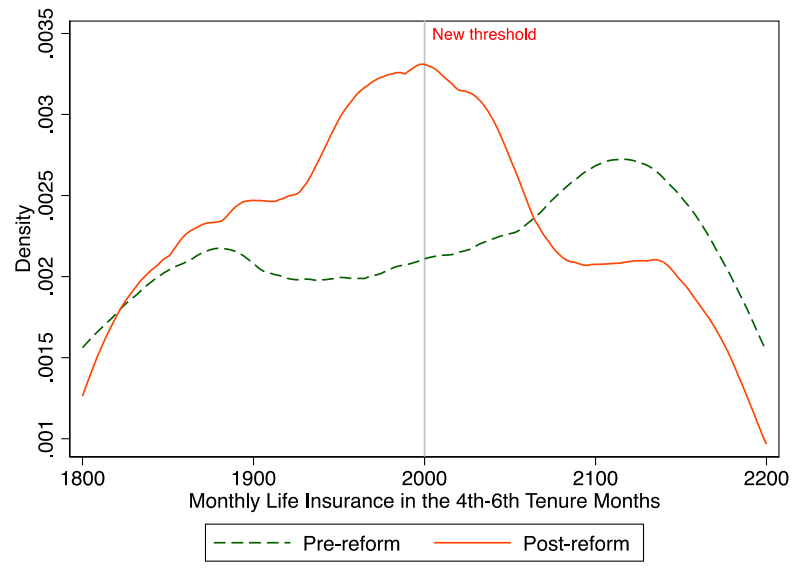

(B) The second level commission threshold

Figure A5: Distributions of Life Insurance Commission around Thresholds for $4^{\text {th }}-6^{\text {th }}$

\section{Tenure Months}

Notes: The figure plots the distributions of life insurance commission around the commission thresholds of the old (green solid lines) and new (red solid lines) compensation schemes for the $4^{\text {th }}-6^{\text {th }}$ tenure months. Panels (A) and (B) present from the lowest to the highest commission threshold, respectively. These figures are (Epanechnikov) kernel density plots. 


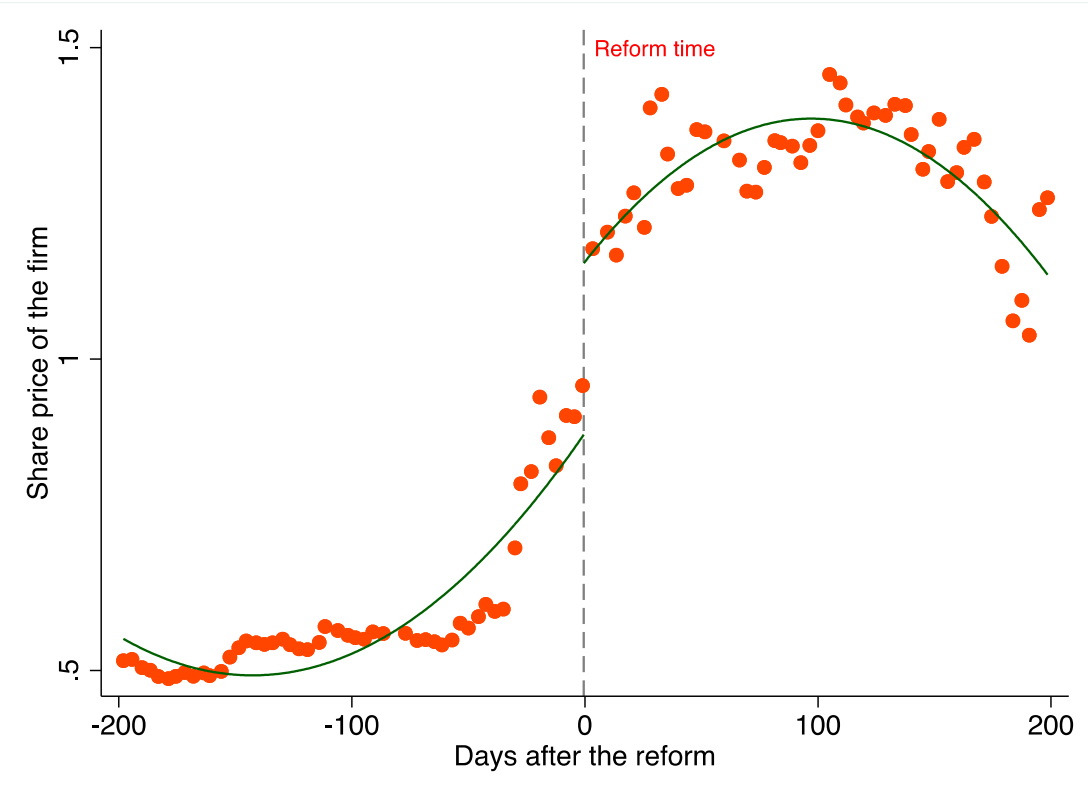

(A) Share price of the firm

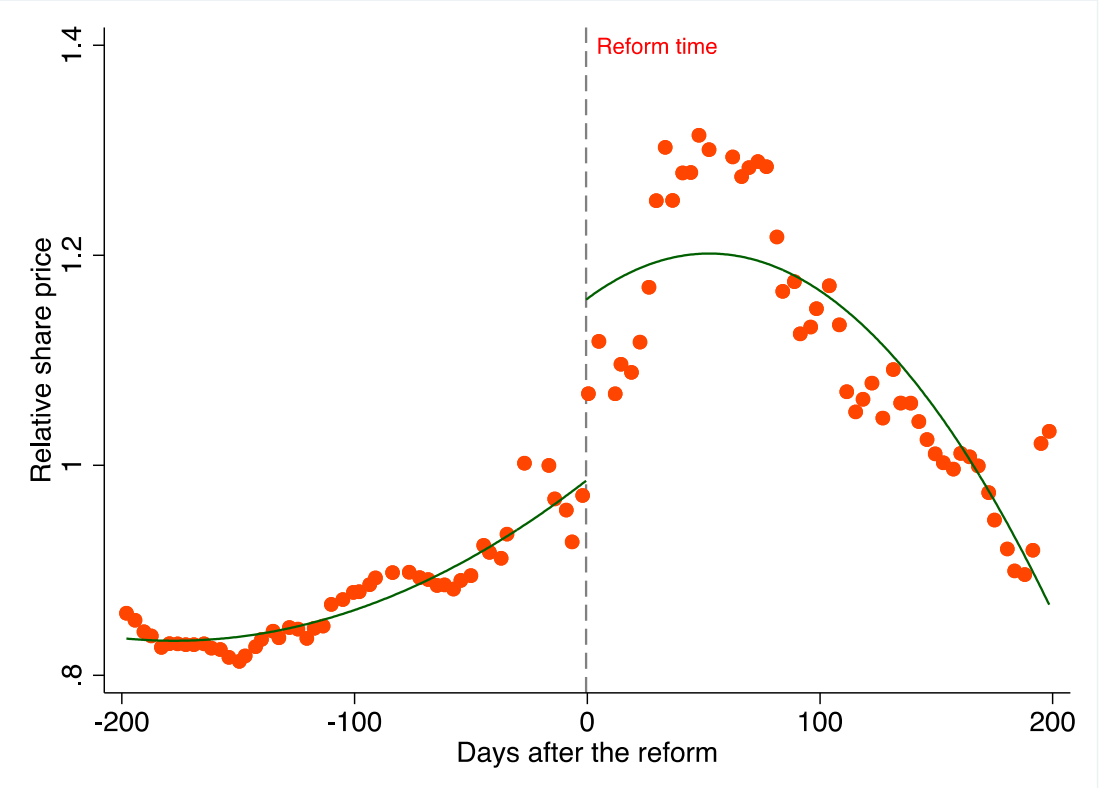

(B) Share price of the firm relative to its main competitor

\section{Figure A6: Share Price of the Firm and of the Firm relative to its Main Competitor}

Notes: The figure shows the share price of the firm (panel (A)) and of the firm relative to its main competitor (panel (B)) during the period from 200 days before to 200 days after the introduction of the new non-linear incentive system. In panel (A) the Y-axis is the share price of the firm, which is scaled to be 1 on the new-system announcement date. In panel (B) the Y-axis denotes the ratio between the share price of the firm and its main competitor, which is scaled to be 1 on the new-system announcement date. Each dot in the two figures represents the average share price in a four-day bin. The green lines are the quadratic fit based on the daily share price data. 
Table A1: Main Result---Changes to the Probability of Being Bonus Winners Scheme

\begin{tabular}{|c|c|c|c|c|c|c|c|c|c|}
\hline \multirow[b]{2}{*}{ Variables } & (1) & (2) & (3) & (4) & $(5)$ & (6) & (7) & (8) & (9) \\
\hline & \multicolumn{9}{|c|}{ Bonus winner $(=1)$} \\
\hline & \multicolumn{9}{|c|}{ Panel A: Treatment group } \\
\hline After & $\begin{array}{l}0.029 * * * \\
(0.007)\end{array}$ & $\begin{array}{l}0.083 * * * \\
(0.011)\end{array}$ & $\begin{array}{l}0.125^{* * *} \\
(0.016)\end{array}$ & $\begin{array}{l}0.123 * * * \\
(0.023)\end{array}$ & $\begin{array}{l}0.065^{* *} \\
(0.026)\end{array}$ & $\begin{array}{l}0.059 * * * \\
(0.015)\end{array}$ & $\begin{array}{r}0.015 \\
(0.019)\end{array}$ & $\begin{array}{l}0.111 * * * \\
(0.026)\end{array}$ & $\begin{array}{l}0.071 * * * \\
(0.022)\end{array}$ \\
\hline Baseline sample mean & 0.009 & 0.032 & 0.089 & 0.234 & 0.356 & 0.043 & 0.113 & 0.067 & 0.049 \\
\hline Observations & 4,190 & 4,190 & 4,190 & 4,190 & 4,190 & 3,480 & 3,480 & 2,011 & 1,271 \\
\hline R-squared & 0.441 & 0.542 & 0.539 & 0.520 & 0.548 & 0.584 & 0.614 & 0.576 & 0.483 \\
\hline Sales commission threshold & $>=8000$ & $>=4000$ & $>=2000$ & $>=1000$ & $>=500$ & $>=2000$ & $>=800$ & $>=1200$ & $>=1600$ \\
\hline Tenure months & $1^{\text {st }}-3^{\text {rd }}$ & $1^{\text {st }}-3^{\text {rd }}$ & $1^{\text {st }}-3^{\text {rd }}$ & $1^{\text {st }}-3^{\text {rd }}$ & $1^{\text {st }}-3^{\text {rd }}$ & $4^{\text {th }}-6^{\text {th }}$ & $4^{\text {th }}-6^{\text {th }}$ & $7^{\text {th }}-9^{\text {th }}$ & $10^{\text {th }}-12^{\text {th }}$ \\
\hline No. of agents & 1710 & 1710 & 1710 & 1710 & 1710 & 1564 & 1564 & 953 & 597 \\
\hline Agent FE & $\mathrm{x}$ & $\mathrm{x}$ & $\mathrm{x}$ & $\mathrm{x}$ & $\mathrm{x}$ & $\mathrm{x}$ & $\mathrm{x}$ & $\mathrm{x}$ & $\mathrm{x}$ \\
\hline Tenure month FE & $\mathrm{x}$ & $\mathrm{x}$ & $\mathrm{x}$ & $\mathrm{x}$ & $\mathrm{x}$ & $\mathrm{x}$ & $\mathrm{x}$ & $\mathrm{x}$ & $\mathrm{x}$ \\
\hline \multirow[t]{2}{*}{ Calendar month linear trend } & $\mathrm{x}$ & $\mathrm{x}$ & $\mathrm{x}$ & $\mathrm{x}$ & $\mathrm{x}$ & $\mathrm{x}$ & $\mathrm{x}$ & $\mathrm{x}$ & $\mathrm{x}$ \\
\hline & \multicolumn{9}{|c|}{ Panel B: Control group } \\
\hline After & $\begin{array}{c}0.005 \\
(0.005)\end{array}$ & $\begin{array}{c}0.007 \\
(0.009)\end{array}$ & $\begin{array}{c}0.002 \\
(0.011)\end{array}$ & $\begin{array}{c}0 . \overline{003} \\
(0.014)\end{array}$ & $\begin{array}{c}-0.005 \\
(0.015)\end{array}$ & $\begin{array}{c}0.002 \\
(0.011)\end{array}$ & $\begin{array}{c}0.001 \\
(0.015)\end{array}$ & $\begin{array}{c}0.002 \\
(0.013)\end{array}$ & $\begin{array}{c}-0.000 \\
(0.014)\end{array}$ \\
\hline Baseline sample mean & 0.005 & 0.015 & 0.036 & 0.064 & 0.087 & 0.036 & 0.071 & 0.057 & 0.044 \\
\hline Observations & 2,367 & 2,367 & 2,367 & 2,367 & 2,367 & 2,367 & 2,367 & 2,367 & 2,367 \\
\hline R-squared & 0.241 & 0.344 & 0.416 & 0.457 & 0.511 & 0.416 & 0.449 & 0.460 & 0.398 \\
\hline Sales commission threshold & $>=8000$ & $>=4000$ & $>=2000$ & $>=1000$ & $>=500$ & $>=2000$ & $>=800$ & $>=1200$ & $>=1600$ \\
\hline Tenure months & $13^{\text {th }}-18^{\text {th }}$ & $13^{\text {th }}-18^{\text {th }}$ & $13^{\text {th }}-18^{\text {th }}$ & $13^{\text {th }}-18^{\text {th }}$ & $13^{\text {th }}-18^{\text {th }}$ & $13^{\text {th }}-18^{\text {th }}$ & $13^{\text {th }}-18^{\text {th }}$ & $13^{\text {th }}-18^{\text {th }}$ & $13^{\text {th }}-18^{\text {th }}$ \\
\hline No. of agents & 1710 & 1710 & 1710 & 1710 & 1710 & 1564 & 1564 & 953 & 597 \\
\hline Agent FE & $\mathrm{x}$ & $\mathrm{x}$ & $\mathrm{x}$ & $\mathrm{x}$ & $\mathrm{x}$ & $\mathrm{x}$ & $\mathrm{x}$ & $\mathrm{x}$ & $\mathrm{x}$ \\
\hline Tenure month FE & $\mathrm{x}$ & $\mathrm{x}$ & $\mathrm{x}$ & $\mathrm{x}$ & $\mathrm{x}$ & $\mathrm{x}$ & $\mathrm{x}$ & $\mathrm{x}$ & $\mathrm{x}$ \\
\hline Calendar month linear trend & $\mathrm{x}$ & $\mathrm{x}$ & $\mathrm{x}$ & $\mathrm{x}$ & $\mathrm{x}$ & $\mathrm{x}$ & $\mathrm{x}$ & $\mathrm{x}$ & $\mathrm{x}$ \\
\hline
\end{tabular}

Notes: This table reports the probability of meeting the life insurance commission thresholds the new compensation scheme. The regression sample is restricted to a narrow time window, i.e., from October 2014 to March 2015. Panel (A) presents the estimates for agents in their $1^{\text {st }} 12^{\text {th }}$ tenure months. As a placebo test, in Panel (B) we displays the estimates for agents in their $13^{\text {th }}-18^{\text {th }}$ tenure months. All standard errors are clustered at the agent level.

$* * * \mathrm{p}<0.01, * * \mathrm{p}<0.05, * \mathrm{p}<0.1$ 
Table A2: Impacts of the New Incentive System on Bonuses

\begin{tabular}{|c|c|c|c|c|}
\hline \multirow[b]{3}{*}{ Tenure months } & \multicolumn{4}{|c|}{ Treatment group } \\
\hline & $(1)$ & (2) & (3) & (4) \\
\hline & $1^{s t}-3^{r d}$ & $4^{\text {th }}-6^{\text {th }}$ & $7^{\text {th }}-9^{\text {th }}$ & $10^{\text {th }}-12^{\text {th }}$ \\
\hline & \multicolumn{4}{|c|}{ Bonus (RMB) } \\
\hline Baseline sample mean (RMB) & 766.5 & 328.3 & 282.2 & 271.9 \\
\hline Baseline estimates & $\begin{array}{l}51.1 * \\
(28.1)\end{array}$ & $\begin{array}{c}71.6^{* * *} \\
(18.5)\end{array}$ & $\begin{array}{c}37.7 * * \\
(18.9)\end{array}$ & $\begin{array}{c}61.4 * * * \\
(20.1)\end{array}$ \\
\hline Estimates with agent FE & $\begin{array}{c}96.0 * * * \\
(28.9)\end{array}$ & $\begin{array}{c}58.4 * * * \\
(18.1)\end{array}$ & $\begin{array}{c}48.5^{* *} \\
(20.6)\end{array}$ & $\begin{array}{c}65.5 * * * \\
(18.9)\end{array}$ \\
\hline No. of agents & 1,710 & 1,564 & 953 & 597 \\
\hline Observations & 4,190 & 3,480 & 2,011 & 1,271 \\
\hline
\end{tabular}

Notes: This table reports the changes to the bonuses received by the agents under the new non-linear compensation scheme. The regression sample is restricted to a narrow time window from October 2014 to March 2015, i.e., three months before and after the reform. Each coefficient denotes an independent regression. The leftmost column describes the specification. In baseline estimates, we control agent's demographic characteristics, tenure month fixed effects, and calendar month linear trend following Equation (2). Demographic characteristics include female dummy, urban dummy, education level indicators, and age. For estimates with agent $F E$, we further control agent fixed effects in Equation (2).

$* * * \mathrm{p}<0.01, * * \mathrm{p}<0.05, * \mathrm{p}<0.1$ 
Table A3: Estimates Based on the Difference-in-Differences Specification

\begin{tabular}{|c|c|c|c|c|}
\hline Tenure months & $\begin{array}{c}(1) \\
1^{s t}-3^{r d}\end{array}$ & $\begin{array}{c}(2) \\
4^{\text {th }}-6^{t h}\end{array}$ & $\begin{array}{c}(3) \\
7^{t h}-9^{t h}\end{array}$ & $\begin{array}{c}\text { (4) } \\
10^{t h}-12^{\text {th }}\end{array}$ \\
\hline & \multicolumn{4}{|c|}{ Panel A: Life insurance commission (RMB) } \\
\hline Baseline sample mean (RMB) & 766.5 & 328.3 & 282.2 & 271.9 \\
\hline \multirow[t]{2}{*}{ Post-reform*Treatment group } & $\begin{array}{c}290.2 * * * \\
(56.6)\end{array}$ & $\begin{array}{c}140.7 * * \\
(61.1)\end{array}$ & $\begin{array}{c}120.3 * * \\
(52.5)\end{array}$ & $\begin{array}{c}157.6^{* * *} \\
(56.4)\end{array}$ \\
\hline & \multicolumn{4}{|c|}{ Panel B: Other insurance commission (RMB) } \\
\hline Baseline sample mean (RMB) & 119.6 & 57.3 & 48.3 & 42.3 \\
\hline \multirow[t]{2}{*}{ Post-reform*Treatment group } & $\begin{array}{c}-23.6 * * \\
(10.9)\end{array}$ & $\begin{array}{l}-13.6 \\
(9.3)\end{array}$ & $\begin{array}{l}-19.4 \\
(18.6)\end{array}$ & $\begin{array}{c}-17.1 * * \\
(7.7)\end{array}$ \\
\hline & \multicolumn{4}{|c|}{ Panel C: Withdrawn commission (RMB) } \\
\hline Baseline sample mean (RMB) & 64.5 & 44.2 & 39.8 & 44.3 \\
\hline Post-reform*Treatment group & $\begin{array}{c}57.7 * * * \\
(14.1)\end{array}$ & $\begin{array}{c}39.6 * * \\
(18.2)\end{array}$ & $\begin{array}{c}70.8 * * * \\
(21.6)\end{array}$ & $\begin{array}{c}53.6 * * \\
(25.5)\end{array}$ \\
\hline Observations & 6,557 & 5,847 & 4,378 & 3,638 \\
\hline Agent FE & $\mathrm{x}$ & $\mathrm{x}$ & $\mathrm{x}$ & $\mathrm{x}$ \\
\hline Tenure month FE & $\mathrm{x}$ & $\mathrm{x}$ & $\mathrm{x}$ & $\mathrm{x}$ \\
\hline Year-month FE & $\mathrm{x}$ & $\mathrm{x}$ & $\mathrm{x}$ & $\mathrm{x}$ \\
\hline
\end{tabular}

Notes: This table reports the estimates based on the difference-in-differences specification. Panels (A), (B), and (C) present the effects on life, other, and withdrawn commission, respectively. Each cell represents an independent regression. The treatment groups in columns (1)-(4) are the $1^{\text {st }}-3^{\text {rd }}, 4^{\text {th }}-6^{\text {th }}, 7^{\text {th }}-9^{\text {th }}$, and $10^{\text {th }}-12^{\text {th }}$ tenure months, respectively. The control group is the $13^{\text {th }}-18^{\text {th }}$ tenure months. The regression sample is the same as that in Table 2, i.e., from October 2014 to March 2015. All standard errors are clustered at the agent level. $* * * \mathrm{p}<0.01, * * \mathrm{p}<0.05, * \mathrm{p}<0.1$ 


\section{Appendix B}

\section{B.1 Gaming by selling insurance to unhealthy/unqualified customers}

The insurance-claim data cover every consumer who purchased insurance from an agent before 2016. It tells us whether agents sold more insurance products to unhealthy/unqualified customers under the new incentive system. We gather data on claims for agents who joined the firm between October 2013 and April 2015, divided into six groups by their contract start time, i.e., October-December 2013, January-March, April-June, July-September, and OctoberDecember 2014, and January-April 2015. ${ }^{25}$ Except for the October-December 2013 recruits, agents in the groups were partially or fully covered by the new incentive system in their first 12 months in the firm. ${ }^{26}$ By comparing claims for the six groups, we can test whether the new compensation scheme led agents to sell more insurance to unhealthy/unqualified customers.

Given the data structure, we employ the following specification:

$$
\text { Claims }_{i}=\beta_{0}+\beta_{1} G_{i}^{1}+\beta_{2} G_{i}^{2}+\beta_{3} G_{i}^{3}+\beta_{4} G_{i}^{4}+\beta_{5} G_{i}^{5}+Z_{i}^{\prime} \beta_{6}+\varphi_{i},
$$

where Claims $_{i}$ represents the life insurance claim dummy or claim amount. $G_{i}^{1}-G_{i}^{5}$ are five binary variables, indicating the five groups of the agents whose contract start date is in January-March, April-June, July-September, and October-December 2014, and January-April 2015, respectively. The agents who joined the company in between October and December 2013 is used as the reference group. $X_{i}^{\prime}$ is a vector of control variables, including tenure month in January 2016, gender, urban status, education levels, and age in 2016. $\varphi_{i}$ is a random error term. Given the five groups have different exposures to the new compensation scheme, we would expect that $\beta_{5}>$

\footnotetext{
${ }^{25}$ Agents who joined the firm after April 2015 are excluded because very few of them have insurance claims cases in 2016. Our results are unchanged by extending the sample period to June or September 2015.

${ }^{26}$ Table B1 shows the treatment status of the six groups.
} 
$\beta_{4}>\beta_{3}>\beta_{2}>\beta_{1}>0$, if agents gamed the system in this way, those with more time covered by the new system would sell more insurance products to unhealthy/unqualified customers. Table B2 shows no statistically significant difference in life insurance claims for the six groups, suggesting claim costs do not increase by the new compensation scheme.

\section{B.2 Heterogeneity analysis}

In this section, we estimated the responses of agents with different observed demographic features to see if some groups responded more than others. To examine potential differences in responses to the new compensation scheme among demographic groups, we divided the sample into subgroups based on gender, age, education level, and urban status, respectively. In each case we split agents into two groups, for instance, females and males; above and below age 35; college graduates and above and high-school graduates and below; and urban and rural agents.

Panel (A) of Table B3 shows a mixed pattern of statistically insignificant differences between men and women varying by group. Panel (B) shows no clear pattern of differences by age group. Panel (C) displays larger and more significant responses for high school graduates and below than for college graduates. Panel (D) reports greater impacts among rural agents except for the $10^{\text {th }}-12^{\text {th }}$ tenure month group. 
Table B1: The Treatment Status for Agents by Contract Start Time

\begin{tabular}{ccccc}
\hline \hline & \multicolumn{4}{c}{ Tenure months covered by the new incentive system } \\
\cline { 2 - 5 } Contract start time & $1^{\text {st }}-3^{\text {rd }}$ & $4^{\text {th }}-6^{\text {th }}$ & $7^{\text {th }}-9^{\text {th }}$ & $10^{\text {th }}-12^{\text {th }}$ \\
\hline Oct.-Dec., 2013 & No & No & No & No \\
Jan.-Mar., 2014 & No & No & No & Partially \\
Apr.-Jun., 2014 & No & No & Partially & Yes \\
Jul.-Sep., 2014 & No & Partially & Yes & Yes \\
Oct.-Dec., 2014 & Partially & Yes & Yes & Yes \\
Jan.-Apr., 2015 & Yes & Yes & Yes & Yes \\
\hline \hline
\end{tabular}

Notes: This table summarizes the tenure months covered by the new incentive system in agents' first 12 months in the firm. For the group recruited during October-December 2013, the agents are not covered by the new incentive system in their $1^{\text {st }}-12^{\text {th }}$ tenure months. For individuals who joined the firm in 2014 , they are partially covered by the new incentive system in their $1^{\text {st }}-12^{\text {th }}$ tenure months. For the group joined during January-April 2015 , the agents are fully covered by the new incentive system in their $1^{\text {st }}-12^{\text {th }}$ tenure months. 
Table B2: Side Effect - More Unqualified Customers?

(1)

(2)

Variables Life insurance claims $(=1) \quad$ Claims amount $(1,000 \mathrm{RMB})$

\begin{tabular}{lcc}
\hline Baseline sample mean & 0.01 & 0.24 \\
\cline { 2 - 3 } Joined between Jan.-Apr. 2015 & -0.02 & -0.32 \\
& $(0.01)$ & $(0.50)$ \\
Joined between Oct.-Dec. 2014 & -0.01 & -0.06 \\
& $(0.01)$ & $0.45)$ \\
Joined between Jul.-Sept. 2014 & -0.00 & 0.28 \\
& $(0.01)$ & $0.46)$ \\
Joined between Apr.-Jun. 2014 & -0.01 & -0.09 \\
& $(0.01)$ & $0.19)$ \\
Joined between Jan.-Mar. 2014 & -0.00 & 0.29 \\
& $(0.01)$ & $0.38)$ \\
Tenure month & -0.00 & -0.02 \\
& $(0.00)$ & $0.03)$ \\
& & \\
Observations & 3,264 & 3,264 \\
R-squared & 0.003 & 0.004 \\
Demographic controls & $\mathrm{x}$ & $\mathrm{x}$ \\
\hline
\end{tabular}

Notes: This table presents the effects of the new compensation scheme on the claims of life insurance. The dependent variables in columns (1) and (2) are dummies on whether an agent encountered claims and claims amount of life insurance, respectively. All the estimates are based on Equation (3). The reference group includes the agents who were recruited by the firm between October and December 2013. Demographic control variables include female dummy, urban dummy, education level indicators, and age. All standard errors are heteroscedasticity-consistent.

$* * * \mathrm{p}<0.01, * * \mathrm{p}<0.05, * \mathrm{p}<0.1$ 
Table B3: Heterogeneity Analysis

\begin{tabular}{|c|c|c|c|c|c|}
\hline \multirow[b]{3}{*}{ Tenure months } & \multicolumn{4}{|c|}{ Treatment group } & \multirow{3}{*}{$\begin{array}{c}\text { Control group } \\
(5) \\
13^{\text {th }}-18^{\text {th }} \\
\end{array}$} \\
\hline & (1) & $(2)$ & (3) & (4) & \\
\hline & $1^{s t}-3^{r d}$ & $4^{\text {th }}-6^{\text {th }}$ & $7^{\text {th }}-9^{\text {th }}$ & $10^{\text {th }}-12^{\text {th }}$ & \\
\hline & \multicolumn{5}{|c|}{ Panel A: By gender } \\
\hline Female & $\begin{array}{c}297.8 * * * \\
(53.7)\end{array}$ & $\begin{array}{c}160.1 * * \\
(64.2)\end{array}$ & $\begin{array}{c}128.5^{* * * *} \\
(49.0)\end{array}$ & $\begin{array}{l}100.6^{*} \\
(53.5)\end{array}$ & $\begin{array}{c}-4.5 \\
(43.4)\end{array}$ \\
\hline \multirow[t]{2}{*}{ Male } & $\begin{array}{c}287.5^{* * *} \\
(73.5)\end{array}$ & $\begin{array}{c}83.8 \\
(73.6)\end{array}$ & $\begin{array}{l}94.0^{*} \\
(56.1)\end{array}$ & $\begin{array}{l}209.9^{*} \\
(112.5)\end{array}$ & $\begin{array}{c}3.1 \\
(67.8)\end{array}$ \\
\hline & \multicolumn{5}{|c|}{ Panel B: By age } \\
\hline Age $\geq 35$ & $\begin{array}{c}297.8 * * * \\
(53.7)\end{array}$ & $\begin{array}{c}160.1^{* *} \\
(64.2)\end{array}$ & $\begin{array}{c}128.5 * * * \\
(49.0)\end{array}$ & $\begin{array}{l}100.6^{*} \\
(53.5)\end{array}$ & $\begin{array}{c}-4.5 \\
(43.4)\end{array}$ \\
\hline \multirow[t]{2}{*}{ Age $<35$} & $\begin{array}{c}287.5 * * * \\
(73.5)\end{array}$ & $\begin{array}{c}83.8 \\
(73.6)\end{array}$ & $\begin{array}{l}94.0^{*} \\
(56.1)\end{array}$ & $\begin{array}{l}209.9^{*} \\
(112.5)\end{array}$ & $\begin{array}{c}3.1 \\
(67.8)\end{array}$ \\
\hline & \multicolumn{5}{|c|}{ Panel C: By education level } \\
\hline College graduates and above & $\begin{array}{c}297.8 * * * \\
(53.7)\end{array}$ & $\begin{array}{c}160.1^{* *} \\
(64.2)\end{array}$ & $\begin{array}{c}128.5 * * * \\
(49.0)\end{array}$ & $\begin{array}{l}100.6^{*} \\
(53.5)\end{array}$ & $\begin{array}{c}-4.5 \\
(43.4)\end{array}$ \\
\hline \multirow[t]{2}{*}{ High-school graduates and below } & $\begin{array}{c}287.5 * * * \\
(73.5)\end{array}$ & $\begin{array}{c}83.8 \\
(73.6)\end{array}$ & $\begin{array}{l}94.0^{*} \\
(56.1)\end{array}$ & $\begin{array}{l}209.9^{*} \\
(112.5)\end{array}$ & $\begin{array}{c}3.1 \\
(67.8)\end{array}$ \\
\hline & \multicolumn{5}{|c|}{ Panel D: By urban status } \\
\hline Urban agents & $\begin{array}{c}199.9 * * * \\
(60.0)\end{array}$ & $\begin{array}{c}86.5 \\
(68.5)\end{array}$ & $\begin{array}{c}47.8 \\
(54.0)\end{array}$ & $\begin{array}{c}152.1^{* *} \\
(72.9)\end{array}$ & $\begin{array}{l}-37.6 \\
(55.8)\end{array}$ \\
\hline Rural agents & $\begin{array}{c}366.8 * * * \\
(62.8)\end{array}$ & $\begin{array}{c}176.9^{* *} \\
(70.4)\end{array}$ & $\begin{array}{c}184.9 * * * \\
(52.8)\end{array}$ & $\begin{array}{l}125.4 \\
(76.9)\end{array}$ & $\begin{array}{c}39.0 \\
(46.0)\end{array}$ \\
\hline
\end{tabular}

Notes: Panels (A)-(D) of this table report heterogeneity effects by gender, age, education level, and urban status, respectively. The regression sample is restricted to a narrow time window, i.e., from October 2014 to March 2015. Each coefficient denotes an independent regression. The dependent variables are life insurance commission for all regressions. The leftmost column describes the subgroups. We control fixed effects, tenure month fixed effects, and calendar month linear trend following Equation (2) for all regressions. All standard errors are clustered at the agent level.

$* * * \mathrm{p}<0.01, * * \mathrm{p}<0.05, * \mathrm{p}<0.1$ 